\title{
Prace Komitetu Cywilnego Reformy nad przygotowaniem narodowej kodyfikacji prawa cywilnego i procedury cywilnej w przededniu utworzenia Królestwa Polskiego (1814-1815) - edycja źródtowa. Część J
}

\begin{abstract}
Works of the Civil Reform Committee on the Civil Law and Civil Procedure Codification on the Eve of the the Establishment of Kingdom of Poland (18141815) - Historical Source Edition. Part I

The present paper is an introduction to the source edition of thirteen documents concerning the organization of the Civil Reform Committee and the Committee's work on changes in civil law and civil procedure. The Civil Reform Committee was appointed by Tsar Alexander I on 19 May 1814 in connection with the plan to transform the Duchy of Warsaw into the Kingdom of Poland, a Russian client state. Participants of the Committee's works were Adam Jerzy Czartoryski, Mikołaj Nowosilcow, Tomasz Ostrowski, Stanisław Zamoyski, Tadeusz Matuszewicz, Aleksander Linowski, Józef Kalasanty Szaniawski, Tomasz Wawrzecki, Franciszek Grabowski, Antoni Bieńkowski, Józef Koźmian, and Andrzej Horodyski. The Committee's goal was to prepare a reform of the administration, the treasury, and the codes of civil and penal law. The Tsar's guidelines urged the Committee to sever all ties with the French models and to draw from native traditions. As regards civil law and civil procedure, the works reached a moderate degree of advancement. Only outlines of the future codes and fragmentary legislative drafts were prepared. Even though these works may be deemed to have been a beginning of Polish codification of law within the modern meaning of the word, the documents used in this process
\end{abstract}


have been heretofore used sparsely by historians, including historians of law. Thus the need for their publication. At the same time we are publishing fundamental documents concerning the organization of the Committee itself.

Keywords: Civil Reform Committee, Duchy of Warsaw, Congress Kingdom of Poland, Napoleonic Code, civil law, civil procedure

Słowa kluczowe: Komitet Cywilny Reformy, Księstwo Warszawskie, Królestwo Kongresowe, Kodeks Napoleona, prawo cywilne, procedura cywilna

\section{Wprowadzenie ${ }^{1}$}

Artykułem 69 konstytucji Księstwa Warszawskiego z 22 lipca 1807 r. Napoleon Bonaparte zobowiązał polskie elity polityczne do wprowadzenia francuskiego kodeksu cywilnego na ziemie polskie. Wszedł on w życie 1 maja 1808 r. $^{2}$ Narzucenie obcej kodyfikacji wprowadziło elity polityczne Księstwa w konsternację. Większość oczekiwała, że przywrócone zostaną dawne prawa polskie ${ }^{3}$. Nawet we władzach Księstwa silna była grupa zdeklarowanych przeciwników obcego prawa z przewodniczącym Rady Stanu i Rady Ministrów Stanisławem Małachowskim na czele ${ }^{4}$. Mimo to wydane zostało stosowne ustawodawstwo, wprowadzające w życie kodeks Napoleona, a następnie też kodeks postępowania cywilnego oraz kodeks handlowy. Fakt ten przypisać należy determinacji najbardziej wpływowego człowieka w rządzie, ministra sprawiedliwości Feliksa Łubieńskiego, i poparciu uzyskanemu przez niego u monarchy Fryderyka Augusta 5 . Nakaz konstytucyjny został wprowadzony w życie, a niechętne mu kręgi władzy postawione zostały przed faktem dokonanym.

Wyraźna mniejszość, głównie obóz tzw. jakobinów polskich, przyjęła decyzję Napoleona o rozciągnięciu na ziemie polskie francuskiego kodeksu cywilnego $\mathrm{z}$ entuzjazmem. Jakobini oczekiwali wprowadzenia jak najszerszego spektrum rozwiązań i praw napoleońskich ${ }^{6}$, uznając, iż jako wywodzące się z dziedzictwa rewolucji francuskiej mają one walor uniwersalny. Przyjmowali oni a priori wyższość instytucji napoleońskich, wychodząc z założenia, że Bonaparte krzewiący hasła rewolucyjne jest

1 Niniejsza publikacja została przygotowana w ramach projektu „Kodyfikacja narodowa - fantazmat czy realna alternatywa? W kręgu debat nad rodzimym systemem prawa sądowego w konstytucyjnym Królestwie Polskim", finansowanego ze środków Narodowego Centrum Nauki na podstawie umowy nr UMO$-2015 / 18 / \mathrm{E} / \mathrm{HS} 5 / 00762$.

2 Dziennik Praw [Księstwa Warszawskiego], t. I, s. XXXVI, Nr 2, s. 46-47; Nr 9, s. 195-201; Nr 10, s. 231-236.

3 A. Kraushar, W setna rocznice Kodeksu Napoleona, „Gazeta Sądowa Warszawska” 1908, nr 22, z dnia 28 V, s. 331-332; K. Sójka-Zielińska, Kodeks Napoleona. Historia i wspótczesność, Warszawa 2008, s. $195-196$.

4 T. Mencel, L'Introduction du Code Napoléon dans le Duché du Varsovie (1808), CPH, 1949, t. 1, z. 2, s. $146-148$.

5 W. Sobociński, Rozwój ustawodawstwa cywilnego w Królestwie Polskim $i$ w Rosji do rosyjskiej reformy sądowej (Zarys historyczno-porównawczy), „Annales Universitatis Mariae Curie-Skłodowska” 1965, sectio G: Ius, vol. 12, s. 122.

6 M. Kallas, Konstytucja Księstwa Warszawskiego - jej powstanie, systematyka i główne instytucje w związku z normami szczegółowymi i praktyka, Toruń 1970, s. 28. 
nośnikiem ogólnoludzkiego postępu cywilizacyjnego, a zatem proponowane przez niego rozwiązania prawne godne są recepcji jako ,wieczne, niewzruszone, ogólne, nieodmienne dla wszystkich, czasów, miejsc i krajów"7. Patron ideowy jakobinów - Hugo Kołłątaj - wieszczył, iż nadchodzi czas, gdy „mieszkaniec jakiej bądź części ziemi, w którąkolwiek uda się stronę [...] znajdzie w każdym kraju [...] tę samą konstytucję, też same prawa" . W rezultacie, wyznając oświeceniową wiarę w sprawcze możliwości prawa stanowionego, i Kołłątaj, i osoby bliskie mu światopoglądowo zdawały się być przeświadczone o tym, że napoleońskie kodeksy, czy też napoleońska konstytucja, jeśli tylko zostaną przyjęte, to niechybnie staną się siłą napędową postępowych przeobrażeń polskiej rzeczywistości ${ }^{9}$. Według wyobrażeń polskich jakobinów na gruncie stworzonym przez rewolucyjne prawa francuskie Napoleona powstanie nowoczesne państwo, wprowadzające w życie nowy porządek społeczny oparty na zasadach prawa natury. Z oczywistych więc względów głęboko osadzone w rzeczywistości feudalnej anachroniczne prawa polskie były dla nich nie do przyjęcia w zmienionej rzeczywistości ideowo-politycznej i społeczno-gospodarczej, w jakiej znalazły się ziemie polskie po rozbiorach, na początku XIX w.

Dominowała jednak niechęć do francuskich urządzeń, czy to w sferze ustrojowej, czy to w dziedzinie prawa prywatnego. Krytyka nie traciła na sile, bądź wręcz narastała. Coraz częściej jawnie manifestowana wrogość do napoleońskiej kodyfikacji związana była m.in. $\mathrm{z}$ faktem, iż niektóre instytucje i zasady kodeksowe (takie jak równość wobec prawa, świecki charakter małżeństwa, postępowanie egzekucyjne chroniące w znacznie większym stopniu interesy wierzyciela itd. niż to miało miejsce w okresie staropolskim) wywoływały poczucie zagrożenia bądź wprost naruszały interesy warstw uprzywilejowanych, zarówno duchowieństwa, jak i ziemiaństwa. Moment kulminacyjny zbiegł się z upadkiem francuskiego protektoratu, który nastąpił w wyniku klęski Wielkiej Armii w wyprawie na Rosję. Kiedy na początku 1813 r. Księstwo Warszawskie znalazło się pod okupacją rosyjską, w kraju rozbrzmiewał już powszechnie „,wielki krzyk” na kodeks Napoleona. Ówczesny wiceprezydent Warszawy Stanisław Węgrzecki, formułując swoje Przestrogi do utworzenia Królestwa Polskiego, datowane na 20 marca 1813 r., wskazywał, że: „[...] ci nawet krzyczą, którzy go wcale nie znają, nie czytali, a mówią, że nie jest do klimatu stosowny [...] szlachcic boi się kodeksu, aby powoli nie utracić swego państwa nad chłopem, boli go, że w jednym trybunale z mieszczaninem i chłopem stawa, że jeden kodeks do sukcesji dla niego i dla mieszczanina [...] duchowni cierpią nad oddaniem religijnych obrządków sumieniu i nad wolną czcią"10.

Ustawa przedspoleczna Towarzystwa Republikanów z 1798 r. Cyt. za: M. Handelsman, Rozwój narodowości nowoczesnej, thum. J. Sękowski, Warszawa 1973, s. 169, 174.

8 H. Kołłątaj, Uwagi nad teraźnieyszym potożeniem tej części ziemi polskiej, którą od pokoiu tylżyckiego zaczęto zwać Xięstwem Warszawskim, Lipsk 1808, s. 127.

9 B. Leśnodorski, Liberatowie, „, technokraci” i republikanie [w:] idem, Historia i wspótczesność, Warszawa 1967, s. 224-225.

10 S. Węgrzecki, Przestrogi do utworzenia Królestwa Polskiego [w:] Wybór tekstów źródtowych z historii Polski w latach 1795-1864, red. S. Kieniewicz, T. Mencel, W. Rostocki, Warszawa 1956, s. 188. Zob. też: T. Mencel, Feliks Łubieński: minister sprawiedliwości Księstwa Warszawskiego (1758-1848), Warszawa 1953, s. 64-70; W. Sobociński, Historia ustroju i prawa Księstwa Warszawskiego, Warszawa 1964, s. 203. 
Negatywny stosunek opinii publicznej do kodeksu Napoleona wynikał z emocjonalnej niechęci do obcego prawa, godzącego w rodzime zwyczaje i tradycje ${ }^{11}$. Przyczyny tego stanu rzeczy niezwykle trafnie rekapitulował prominentny prawnik epoki, sędzia Sądu Kasacyjnego Antoni Wyczechowski w swym memoriale z końca 1815 r.:

Skarżono się w Księstwie na niestosowność Kodeksu i tego przyczyny są następujące [wyliczał Wyczechowski]: a) żadne prawo nie może być zupełnie stosownym do obcego kraju. b) Prawo Kodeksu zawierające w sobie tak wielką reformę praw osobistych musi się wielu nie podobać. c) Prawo Kodeksu jest przez samych rodaków wykonane [tj. wykonywane], którzy jeszcze w takim krótkim czasie nie mogli dostatecznie zgłębić ducha jego, a zatem wady wykonania mogą być uważane za wady prawodawstwa samego. d) Wiadomość praw Kodeksu jest najbardziej upowszechnioną, a zatem większa jest na nie uwaga zwrócona, jak na wszelkie inne obce prawa. Co się rzekło o Kodeksie cywilnym, stosuje się oraz do Kodeksu procedury, do Kodeksu handlowego i do Organizacji sądowej, które to części uważać należy jako części dopełniające Kodeks cywilny ${ }^{12}$.

Niechęć do prawa francuskiego narastała, stale podsycana przez gromadzącą się szlachtę (zwłaszcza na sejmach ${ }^{13}$ ) oraz propagandę Kościoła katolickiego ${ }^{14}$. Pożywką dla krytyki były zasady kodeksowe gwarantujące równość wobec prawa w dziedzinie prawa cywilnego i nieuznające przywilejów urodzenia, narodowości i wyznania. Prawidłowa implementacja kodeksu wymagała więc przebudowy stosunków społecznych ${ }^{15}$, tym bardziej że kodeks wyraźnie stał na gruncie zasady prymatu prawa pozytywnego, na mocy którego w każdej chwili możliwe było zniesienie obowiązujących praw i zwyczajów. Tym samym jego obowiązywanie ziemiaństwo odczuwało jako nieustanne zagrożenie dla swej uprzywilejowanej pozycji ${ }^{16}$. Na to nakładał się wrogi stosunek do kodeksu Kościoła katolickiego protestującego przeciwko przepisom o urzędach stanu cywilnego i o świeckim charakterze małżeństwa, którego święty węzeł mógłby odtąd być rozwiązywany niezgodnie z prawem kanonicznym ${ }^{17}$. To obawa przed zmianą stosunków społecznych i utratą uprzywilejowanej pozycji przez szlachtę i duchowieństwo powodowały zatem zmasowaną krytykę przejmowanego prawa. I odwrotnie: dążenie do petryfikacji stosunków społecznych skutkowało próbami idealizacji prawa przedrozbiorowego ${ }^{18}$.

11 M. Gałędek, The Problem of Non-Adaptability National Legal Heritage. Discussion on the Reform of Civil Law in Poland in the Course of Work of Reform Committee in 1814, „,Romanian Journal of Comparative Law” 2017, t. 8, z. 1, s. 16-17. Zob. też: J.J. Litauer, Przeciwnicy Kodeksu, „Gazeta Sądowa Warszawska” 1908, nr 22, z dnia 28 V, s. 363-367; S. Askenazy, Zagrożenie Kodeksu Napoleona przy utworzeniu Królestwa Polskiego [w:] idem, Szkice i portrety, Warszawa 1937, s. 374-376; H. Grynwaser, Kodeks Napoleona w Polsce [w:] idem, Pisma, t. I, Wrocław 1951, s. 54-79.

12 Biblioteka Książąt Czartoryskich [dalej: BKC], sygn. 5259 IV, s. 77-78.

13 T. Mencel, Introduction..., s. 146-147, 167, 185.

14 Ibidem, s. 182-184. Por. M. Gałedek, A. Klimaszewska, A Controversial Transplant? The Debate on the Adaptation of the Napoleonic Code on Polish Territory in the Early Nineteenth Century, ,Journal of Civil Law Studies" 2018, t. 11, z. 2, s. 273-276.

15 T. Mencel, Introduction..., s. 148, 152, 153.

16 Ibidem, s. 152, 154-155, 180-181.

17 P. Pomianowski, Z problematyki rozwodów w Księstwie Warszawskim, CPH, 2013, t. 65, z. 2, s. 103 , 108-110; idem, Rozwód w XIX wieku na centralnych ziemiach polskich. Praktyka stosowania Kodeksu Napoleona $w$ latach 1808-1852, Warszawa 2018, s. 66-69.

18 J. Bardach, Recepcja w historii państwa i prawa [w:] idem, Themis a Clio, czyli prawo a historia, Warszawa 2001, s. 80-81. 
Zwycięski cesarz rosyjski Aleksander I podjął decyzję o utrzymaniu polskiej państwowości i jeszcze przed kongresem wiedeńskim postanowił zainicjować proces przebudowy ram ustrojowo-prawnych Księstwa Warszawskiego, oddając ster przygotowań $\mathrm{w}$ ręce polskie. $\mathrm{W}$ panującej podówczas atmosferze likwidacji wszystkiego, co mogło uchodzić za dorobek rewolucji, los prawa francuskiego recypowanego na ziemiach polskich zdawał się przesądzony. Nie może też dziwić, że w przededniu utworzenia Królestwa Polskiego niezmiernie rzadko podejmowano się jego otwartej obrony. Napoleońskie dziedzictwo uznawano za obce, niedostosowane do polskich realiów i niezasymilowane przez społeczeństwo. Dlatego też wprowadzone w Księstwie Warszawskim kodeksy prawa prywatnego, podobnie jak chociażby wzorowany na napoleońskim ustrój administracyjny, uznawane były za wymagające niezwłocznego zastąpienia przez instytucje bliższe rodzimej tradycji, a zatem czerpiące z przedrozbiorowych wzorców. To z jednej strony.

$Z$ drugiej natomiast na forum Komitetu Cywilnego Reformy możemy zaobserwować pierwszą - jeszcze dość nieśmiałą - próbę obrony francuskiego prawodawstwa podjętą przez wybitnego jurystę sędziego Sądu Apelacyjnego, Antoniego Bieńkowskiego ${ }^{19}$. Stał się on centralną postacią Komitetu i niewątpliwie też autorytetem w kwestii przygotowywania reformy prawa sądowego. Zarazem w 1814 r. Bieńkowski przecierał dopiero szlaki i kładł podwaliny pod ruch progresywny, który stopniowo wzmacniał się i uzyskiwał przewagę w latach następnych. Wystąpienia Bieńkowskiego na forum Komitetu zwiastowały bowiem nadchodzący proces konsolidacji przedstawicieli ścisłej elity prawniczej Księstwa Warszawskiego na rzecz częściowego choćby utrzymania bądź inspirowania się francuskim prawodawstwem $\mathrm{w}$ toku prac nad tworzeniem nowej narodowej kodyfikacji. Elitę tę będzie tworzył krąg wykładowców akademickich z Janem Wincentym Bandtkie oraz Franciszkiem Ksawerym Szaniawskim na czele, a także sędziów, wśród których prym wiedli - wspomniani już - Antoni Bieńkowski, Antoni Wyczechowski czy też Michał Woźnicki. Środowisko to odgrywać będzie też pierwszoplanowe role w świecie prawniczym Królestwa Polskiego, a jego wpływ na kierunek prac kodyfikacyjnych prowadzonych w dobie konstytucyjnej okaże się przemożny. Argumentacja i poczynania Bieńkowskiego na forum Komitetu Cywilnego Reformy - które stanowią centralny punkt materiałów źródłowych publikowanych w niniejszej serii - podobnie jak argumenty podnoszone w latach następnych przez innych rzeczników wzorowania się na nowoczesnym prawodawstwie zachodnim już w $1814 \mathrm{r}$. zaczynały trafiać do przekonania osobom decydującym o kierunku prac kodyfikacyjnych. W rezultacie, poczynając już od końca 1815 r., od momentu podjęcia działalności przez Komisję Kodeksową, a zwłaszcza od momentu, gdy członkami Komisji Rządowej Sprawiedliwości, a zarazem radcami stanu stali się ,progresywiści” w osobach Antoniego Wyczechowskiego oraz Michała Woźnickiego ${ }^{20}$, zdobyli oni wyraźną przewagę nad tradycjonalistami, których pozycja w dobie konstytucyjnej stopniowo była osłabiana ${ }^{21}$.

19 Antoni Bieńkowski (1760-1834) - w czasach Księstwa Warszawskiego i Królestwa Polskiego pełnił funkcję sędziego Sądu Apelacyjnego. W Komitecie Cywilnym Reformy wszedł w skład Sekcji Sądowej, skupiając się na przygotowaniu reformy prawa sądowego.

20 Zob. W. Witkowski, Uwagi o urzędzie ministra sprawiedliwości w Królestwie Polskim (1815-1867), „Acta Universitatis Wratislaviensis” 2010, no. 3270, prawo CCCXI, s. 267-268.

21 Szerzej o procesie konsolidowania się i uzyskiwania dominującego wpływu na bieg i kierunek prac kodyfikacyjnych w Królestwie Polskim przez progresywną elitą prawniczą Księstwa Warszawskiego zob. 
Sukcesowi odniesionemu przez obrońców prawa francuskiego, polegającemu na utrzymaniu zasadniczych zrębów francuskiego prawa cywilnego, niewątpliwie sprzyjał fakt, że zainicjowane przez Komitet Cywilny Reformy przygotowania do opracowania nowych kodyfikacji cywilnych na podstawie prawa przedrozbiorowego były zadaniem niezmiernie trudnym. Przed rozbiorami w Koronie nie było przecież kodeksów, które w drugiej dekadzie XIX wieku można było po prostu przywrócić. Problem z nieskodyfikowanym prawem koronnym dobrze ilustruje postępowanie państw zaborczych, których organy musiały - przynajmniej w pewnym zakresie - stosować dawne prawo polskie. Mianowicie w Prusach Zachodnich za źródło prawa polskiego zaborca uznał opracowanie Jana Herburta ${ }^{22}$, a w Prusach Południowych i Nowowschodnich - Antoniego Trembickiego ${ }^{23}$. Natomiast w zaborze austriackim utrzymano w służbie polskich sędziów i nakazano im procedowanie według dotychczasowych zasad ${ }^{24}$. Nie było więc konieczne wytypowanie jednego zbioru praw lub opracowania, które miałyby mieć powagę w sądach. Natomiast w Księstwie Warszawskim za źródło dawnego prawa polskiego (mającego ciągle zastosowanie choćby w sprawach spadkowych, gdy otwarcie spadku nastąpiło przed zaprowadzeniem Landrechtu z 1794 r. i kodeksu cywilnego zachodniogalicyjskiego) uznano Volumina Legum ${ }^{25}$.

Proces przebudowy ustrojowo-prawnej został zainicjowany decyzją o powołaniu „Komitetu do przygotowania projektów względem poprawy wewnętrznego urządzenia kraju Księstwa Warszawskiego"26, wydanej przez cesarza w Paryżu w formie ukazu datowanego na 19 maja $1814 \mathrm{r}$. W dokumencie tym, zaopatrzonym w załączniki opisujące zadania i skład Komitetu, Aleksander określał nowo powołane kolegium po prostu mianem „Comité”, nie nadając mu żadnej własnej nazwy. Jednakże już w podstawowych dokumentach związanych z działalnością tego Komitetu (tj. w rękopisach Biblioteki Książąt Czartoryskich, sygn. 5233 IV, 5236 IV, 5260 IV) posługiwano się zazwyczaj nazwą „Komitet Reformy”. Określenie „Komitet Cywilny” upowszechniło się w okresie późniejszym, dla odróżnienia tegoż kolegium od równolegle działającego w tym samym czasie Komitetu Wojskowego. Zaczyna ono pojawiać się w dokumentach urzędowych dopiero w czasie działalności Rządu Tymczasowego Królestwa Polskiego, tj. w drugiej połowie 1815 r., a więc już po zawieszeniu działalności Komitetu ${ }^{27}$. Z kolei niejako kon-

M. Gałędek, Problem..., s. 7-38; M. Gałędek, A. Klimaszewska, A Controversial Transplant ..., s. 269-298; M. Gałędek, A. Klimaszewska, Stosunek polskich elit do prawa francuskiego po upadku Napoleona, „Studia z Dziejów Państwa i Prawa Polskiego" 2018, t. 21 [w druku]. Edytorzy niniejszego materiału źródłowego prowadzą też dalsze badania nad przedmiotowym zagadnieniem w ramach przywołanego wyżej projektu „Kodyfikacja narodowa - fantazmat czy realna alternatywa?”.

22 J. Herburt, Statuta y przywileje koronne z łacińskiego języka na polskie przetożone, nowym porzadkiem zebrane, Kraków 1570.

${ }_{23}$ A. Trembicki [Trębicki], Prawo polityczne i cywilne Korony Polskiej i Wielkiego Księstwa Litewskiego, to jest: Nowy zbiór praw Obojga Narodów od roku 1347 aż do teraźniejszych czasów, t. 1-2, Warszawa 1789-1791; Dziennik Praw [Księstwa Warszawskiego], t. II, s. 88; Z. Radwański, J. Wąsicki, Wprowadzenie pruskiego prawa krajowego na ziemiach polskich, CPH, 1954, t. 6, z. 1, s. 184-220.

24 S. Grodziski, Studia galicyjskie: rozprawy i przyczynki do historii ustroju Galicji, Kraków 2007, s. $12-13$.

25 Dziennik Praw [Księstwa Warszawskiego], t. II, s. 87.

26 Wykaz pism wystawionych w Komitecie Cywilnym Reformy, BKC, sygn. 5236 IV, s. 5.

27 Zob. Rzad Tymczasowy do Rady Stanu, 28 lipca 1815 [w:] J. Bojasiński, Rzady tymczasowe w Królestwie Polskiem: maj-grudzień 1915, Warszawa 1902, s. 265. 
kurencyjna nazwa „Komitet Organizacyjny” zaczęła być stosowana kilka dekad później. Prawdopodobnie została ona upowszechniona przez Antoniego Ostrowskiego w jego pamiętnikarskiej relacji wydanej dopiero w $1840 \mathrm{r}^{28}$

Można podejrzewać, że załączone do rozkazu dokumenty określające zakres działania Komitetu („Objets dont le Comité doit s'occuper”), a także - per analogiam, bo brak na to bezpośrednich dowodów - ustalające listę osób powołanych do tego kolegium, zostały przygotowane przez ks. Adama Jerzego Czartoryskiego.

Czartoryski był stanowczym przeciwnikiem kodeksu tak ze względów społecznych, jak i politycznych. Jak pisał Szymon Askenazy, Książęe „obcy był instytucjom Księstwa, Kodeksu nie znał, przeciwko wszystkiemu co napoleońskie był przekonany z zasady" ${ }^{29}$. Nie przeszkadzało mu to uważać Kodeksu Napoleona za „dzieło przenikliwości i rozumu”, twierdzić, że należy on do grupy praw „porządniejszych”, z których warto zaczerpnąc to, co „,użyteczne i dobrze widziane”. Decydujące znaczenie miało jednak jego przeświadczenie, że nadanie „obcych praw [...] a z nimi - obcych zwyczajów i czuć” doprowadzi naród polski do „utraty swej oryginalności”, a wraz z nią i utraty „swoich dobrych własności”. W zamian za to naród, który zdecyduje się na taki krok, jakoby „po większej części cudze przywary [...] nabywa”. Czartoryski nie wskazywał, z czego czerpał swoją wiedzę o istnieniu takiej prawidłowości. Na jej podstawie doszedł jednak do wniosku, że „najsmutniejszą jest to kraju koleją, kiedy musi narzucone sobie, choćby i doskonałe, przyjąć prawodawstwo. [Dlatego] lepiej, żeby następnie poprawiał, dopełniał swoje własne instytucje, niż żeby je raptem cudzą siłą i obce przyjął" ${ }^{\prime 30}$. Czartoryski w swym sprzeciwie wobec wprowadzenia do Księstwa Warszawskiego kodeksu Napoleona kierował się też, a może przede wszystkim, motywacjami politycznymi. Mając bowiem na względzie plany przyłączenia do Księstwa guberni zachodnich Cesarstwa (dawnego Wielkiego Księstwa Litewskiego), uważał, że nie jest realnym rozciągnięcie na te tereny prawa francuskiego. W związku z tym, aby dokonać unifikacji prawnej całego tego obszaru, książę był orędownikiem stworzenia kodyfikacji narodowej poprzez wspomnianą już „,poprawę i dopełnianie własnych instytucji”’31.

W pierwszej połowie 1814 r. Czartoryski przebywał w otoczeniu zwycięskiego cesarza we Francji ${ }^{32}$. O przygotowaniach do uregulowania sprawy polskiej, obejmujących najprawdopodobniej także redakcję dokumentów ustanawiających Komitet Cywilny Reformy, Czartoryski informował w swoim Dzienniku. Początkowo mogło się wydawać, że cesarz nie będzie skłonny, aby dać posłuch koncepcjom Czartoryskiego, przez ociąganie się ze zmianą status quo ziem polskich okupowanych przez wojska rosyjskie. W pierwszych swych dziennikowych relacjach z pobytu we Francji, które można łączyć z planami powołania Komitetu, Czartoryski wskazywał na trudności, jakie napotkał w bezpośrednim kontakcie z cesarzem. Wprawdzie na początku marca $1814 \mathrm{r}$. Imperator zezwolił mu na oddanie „zapisków” przygotowanych przez Czartoryskiego najbliż-

28 A. Ostrowski, Żywot Tomasza Ostrowskiego, ministra Rzeczypospolitej później prezesa Senatu Księstwa Warszawskiego i Królestwa Polskiego oraz rys wypadków krajowych od 1763 r. do 1817 r. przez autora pomystów o potrzebie reformy krajowej, t. 2, Paryż 1840, s. 498.

29 S. Askenazy, Zagrożenie..., s. 374.

30 A. Kraushar, W setna rocznice..., s. 332.

31 S. Askenazy, Zagrożenie ..., s. 374; H. Grynwaser, Kodeks..., s. 68-69, 71.

32 Zob. S. Askenazy, Założenie Królestwa Polskiego w 1815 r. [w:] idem, Szkice i portrety..., s. 142. 
szemu współpracownikowi Aleksandra, Aleksemu Arakczejewowi, i obiecał poparcie dla koncepcji Księcia oraz wydanie stosownego ukazu cesarskiego, ale zarazem też Czartoryski wciąż był niespokojny o dalszy los sprawy polskiej, czemu dawał wyraz w swym Dzienniku. Jeszcze w marcu pisał: „Ukaz warszawski dotąd niepodpisany. Moje zabiegi u Arakczejewa i u cesarza próżne oto" 33 . Dopiero w pierwszej połowie kwietnia Czartoryski umieścił wzmiankę o odbyciu audiencji u cesarza, podczas której miał okazję osobiście wręczyć mu „swój plan”’34. Wszystko wskazuje na to, że Książę miał na myśli memoriał z Chaumont datowany na 19 marca, który zawierał podstawowe zasady prawno-państwowe dla przyszłego Królestwa Polskiego, w tym zalecenia, które kilka miesięcy później zaczęły determinować zakres i kierunek prac prowadzonych przez Komitet Cywilny Reformy ${ }^{35}$. Zapewne zawarty w tym piśmie plan, choć niewykluczone, że w jakimś stopniu zmodyfikowany, był następnie „czytany” $i$ ostatecznie ,przyjęty z małymi odmianami" na kolejnym spotkaniu Czartoryskiego z monarchą, które odbyło się po 25 kwietnia $^{36}$, a więc poprzedzało bezpośrednio wydanie długo oczekiwanego ukazu ustanawiającego Komitet Cywilny Reformy. Spośród załączonych do ukazu dziewięciu punktów składających się na Objets dont le Comité doit s'occuper Książę $\mathrm{z}$ pewnością był autorem treści pierwszego i drugiego punktu, ponieważ w tym zakresie dokument cesarski stanowił powtórzenie treści memoriału złożonego Aleksandrowi przez Czartoryskiego 7 marca $1814 \mathrm{r}^{37}$ Nie może więc budzić zdziwienia, że w ślad za przysłanym do Warszawy ukazem do członków Komitetu został wysłany też list od Księcia, w którym wyjaśniał on „zamiary, w jakich powyższy Komitet wyznaczonym został”, informując też, że ,życzenia Jego Imperatorskiej Mości [powinny] być dopełnionymi za przybyciem tego monarchy do Warszawy"38.

Funkcja „prezydującego” (,dyrygującego”) w Komitecie także została powierzona Czartoryskiemu. Książę nie zdążył jednak wrócić do kraju i nie był obecny zarówno na inauguracji prac Komitetu 4 lipca, jak i na kolejnych jego letnich posiedzeniach, podczas których ustalono zasady działania tego kolegium i - na podstawie dyrektyw cesarskich określono harmonogram oraz doprecyzowano zakres prac. Czartoryski pierwszy raz pojawił się na obradach dopiero na 14. sesji dnia 18 sierpnia $^{39} \mathrm{i}$ uczestniczył w nich tylko do 12 września ${ }^{40}$, kiedy to po spotkaniu z cesarzem w Puławach wyjechał na wiele miesięcy z kraju na kongres wiedeński. Książę uczestniczył więc w zaledwie ośmiu posiedzeniach i w czasie swojego krótkiego pobytu nie koncentrował swojej uwagi na kwestiach prawa sądowego. Najprawdopodobniej absorbowały go w tym czasie prace nad - przedstawionym Aleksandrowi w Puławach - projektem Zasad konstytucji Królestwa Polskiego prowadzonym poza Komitetem (który nie uzyskał takich pełnomocnictw), choć przy

33 Dziennik ks. Adama Jerzego Czartoryskiego 1813-1817, oprac. M. Karpińska, Warszawa 2016, s. 303.

34 Ibidem, s. 321.

35 Gosudarstvennyj Archiv Rossijskoj Federacji w Moskwie, Fond 1165, opis 3, dieło 14, k. 2-4; BKC, sygn. 5239 IV, k. 207-214. Zob. też: W.A. Zawadzki, Recenzja Dziennika ks. Adama Jerzego Czartoryskiego 1813-1817, „Kwartalnik Historyczny” 2018, nr 1, s. 208.

36 Dziennik..., s. 325.

37 Por. S. Askenazy, Zagrożenie ..., s. 374-375 (autor ten podaje, że memoriał był datowany na 7 lutego); M. Gałędek, The Problem..., s. 15.

38 BKC, sygn. 5233 IV, s. 8.

39 Ibidem, s. 76.

40 Ibidem, s. 137. 
udziale niektórych jego członków. Natomiast w trakcie posiedzeń Komitetowych skupił się na ustaleniu przewodnich założeń reformy ustroju administracji lokalnej ${ }^{41}$.

Podczas nieobecności Czartoryskiego obradom przewodniczył Mikołaj Nowosilcow, łącząc swoje „zatrudnienia” w Komitecie z funkcją wiceprezesa Rady Najwyższej Tymczasowej ${ }^{42}$. W obu przypadkach koncentrował swoją uwagę na zagadnieniach skarbowych $^{43}$. Obrady toczyły się w „domu” Tomasza Ostrowskiego, prezesa Senatu Księstwa Warszawskiego, nestora polskiej polityki, będącego już u schyłku swego długiego życia (Ostrowski, urodzony w 1735, zmarł w 1817) ${ }^{44}$. Warszawską rezydencją Ostrowskiego, stanowiącą miejsce zebrań Komitetowych, był najprawdopodobniej istniejący do dziś przy ul. Miodowej w Warszawie Pałac Szaniawskich, który podówczas stanowił chyba jedyną nieruchomość w Warszawie należącą do prezesa Senatu.

Ostrowski, podczas sporadycznych nieobecności Nowosilcowa na posiedzeniach Komitetu, przejmował od niego funkcję przewodniczącego jako osoba trzecia na liście członków powołanych do Komitetu przez cesarza ${ }^{45}$. Okoliczność ta mogła dać asumpt synowi Tomasza, Antoniemu, autorowi Żywotu... swojego ojca, do umieszczenia w nim przekłamującej rzeczywistość wzmianki, że Tomasz został wyznaczony na to stanowisko przez cesarza i z urzędu przewodniczył obradom ${ }^{46}$.

Do Komitetu powołanych zostało kilkanaście osób. Poza wspomnianymi już Czartoryskim, Nowosilcowem oraz Ostrowskim na liście, która - co wielce prawdopodobne - ułożona została także przez księcia albo przy wiodącym jego udziale, znaleźli się najbliżsi jego współpracownicy - Stanisław Zamoyski ${ }^{47}$, Tadeusz Matuszewicz

41 Szerzej: M. Gałędek, Koncepcje i projekty nowego ustroju administracji dla przyszłego Królestwa Polskiego. Studium z dziejów myśli administracyjnej, Sopot 2017, s. 100-101, 117-118.

42 Mikołaj Nowosilcow (1761-1838) - w 1813 r. wszedł w skład Rady Najwyższej Tymczasowej jako jej wiceprzewodniczący, w 1815 r. został zaś członkiem Rządu Tymczasowego Królestwa Polskiego. Powołany do Komitetu Cywilnego Reformy pełnił w nim funkcję przewodniczącego (pod nieobecność Czartoryskiego). Stanął też na czele Sekcji Skarbowej Komitetu, prezentując projekt reformy administracji skarbowej. We wrześniu $1814 \mathrm{r}$. uczestniczył w naradzie puławskiej podczas prezentacji projektu Zasad konstytucji.

43 BKC, sygn. 5233 IV, s. 89.

44 Tomasz Ostrowski - w 1791 r. został powołany na urząd podskarbiego nadwornego koronnego i wszedł w skład Straży Praw. W Księstwie Warszawskim został powołany na urząd prezesa Głównej Izby Obrachunkowej w 1808 r. Rok później został wybrany marszałkiem Sejmu, w 1811 r. zaś prezesem Senatu. Wszedł w skład Komitetu Cywilnego Reformy, którego obrady odbywały się w jego domu - Pałacu Szaniawskich.

45 Znajduje to odzwierciedlenie w publikowanych przez nas protokołach 51, 60, 65 i 66 , kiedy to podczas nieobecności Czartoryskiego i Nowosilcowa obradom przewodniczył Ostrowski.

46 A. Ostrowski, Żywot..., s. 498. Niestety, ta błędna informacja zdążyła już rozpowszechnić się w literaturze. Zob. J. Przygodzki, Rada Najwyższa Tymczasowa Księstwa Warszawskiego 1813-1815. Organizacja i działalność, Wrocław 2002, s. 178; idem, Komitet Organizacyjny Cywilny i jego prace nad reorganizacja administracji na terenach Księstwa Warszawskiego, „Acta Universitatis Vratislaviensis” 1999, nr 2144, prawo CCLXIV, s. 151; W. Sobociński, Historia ..., s. 27; J. Bojasiński, Rzady..., s. 17; H. Grynwaser, Kodeks..., s. 71. Nie jest też prawdziwa inna znajdująca się w Żywocie... informacja, iż na członka Komitetu wybrany został Stanisław Staszic.

47 Stanisław Zamoyski (1775-1856) - jako przywódca szlachty galicyjskiej został powołany na prezesa Rządu Centralnego obojga Galicji w 1809 r. W 1814 r. powołano go na prezesa Sekcji Administracyjnej Komitetu Cywilnego Reformy. 


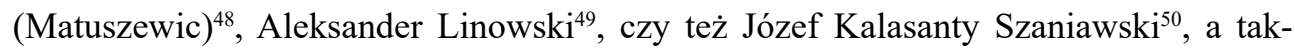
że Tomasz Wawrzecki ${ }^{51}$, Franciszek Grabowski ${ }^{52}$, Antoni Bieńkowski ${ }^{53}$, ksiądz Józef Koźmian ${ }^{54}$ oraz Andrzej Horodyski ${ }^{55}$. Do Komitetu powołane zostały też osoby, które nigdy nie wzięły udziału w jego obradach - przebywający do 1815 r. we Francji były minister spraw wewnętrznych Księstwa Warszawskiego Tadeusz Mostowski, który obejmie tę samą funkcję w przyszłym Królestwie Polskim, Józef Ossoliński - prezes Sądu Apelacyjnego Księstwa - zmarł on już w 1812 r., a jego nominacja wskazuje na brak dobrego rozeznania co do sytuacji w Polsce, i to nie tylko Aleksandra, ale i Czartoryskiego; wreszcie Dominik Kuczyński, który wycofał się już wówczas z życia politycznego.

Jak wspomniano, wśród członków Komitetu znalazło się liczne grono najbliższych współpracowników księcia Adama, choć dalekie od wewnętrznej spoistości i jednorodności przekonań politycznych. Owa grupa „,zołowych polskich statystów, którzy w dobie organizacji Królestwa Polskiego blisko współpracowali z księciem Adamem Jerzym Czartoryskim”, stanowiła swego rodzaju „nieformalne stronnictwo, w którym - paradoksalnie - nie obowiązywała zgoda na głoszone przez przywódcę poglądy, lecz istniała więź charakterystyczna dla stosunków między patronem a klientem" "56. Wśród nich znalazło się wcale liczne grono osób znanych z niechęci do francuskiego prawodawstwa ${ }^{57}$. Zarazem też prace prowadzone przez Komitet są uznawane w literaturze historycznej za

48 Tadeusz Matuszewicz (ok. 1765-1819) - jako poseł Sejmu Czteroletniego był związany z Czartoryskimi. Brał udział w ostatniej fazie prac nad projektem Konstytucji 3 maja. W 1810 r. został mianowany radcą stanu. W 1811 r. objął urząd ministra skarbu Księstwa Warszawskiego. W 1814 r. jako jeden z najbliższych współpracowników Czartoryskiego wszedł w skład Komitetu Cywilnego Reformy i jego Sekcji Skarbowej. Najprawdopodobniej był współautorem projektu Zasad konstytucji.

49 Aleksander Linowski (ok. 1759-1820) - był posłem na Sejm Czteroletni i uczestniczył w pracach przygotowujących Konstytucję 3 maja. W Księstwie Warszawskim został mianowany radcą stanu i angażował się w rozliczne prace legislacyjne. Prawdopodobnie był jednym ze współautorów projektu Zasad konstytucji. Wszedł w skład Sekcji Administracyjnej Komitetu Cywilnego Reformy.

50 Józef Kalasanty Szaniawski (1764-1843) - filozof, na przełomie XVIII i XIX wieku związany ze środowiskiem tzw. jakobinów polskich, w Księstwie Warszawskim i Królestwie Polskim piastował różne urzędy średniego i wyższego szczebla (m.in. był kierownikiem biura cenzury i radcą stanu).

51 Tomasz Wawrzecki (1759-1816) - był posłem na Sejm Czteroletni, a w 1794 r. naczelnikiem insurekcji kościuszkowskiej. W 1813 r. powołany na członka Rady Najwyższej Tymczasowej Księstwa Warszawskiego, następnie w 1815 r. wszedł w skład Rządu Tymczasowego Królestwa Polskiego, z której ramienia „dyrygował” administracją sprawiedliwości, a także odpowiadał za administrację wojskową.

52 Franciszek Grabowski (1750-1836) - był prawnikiem lubelskim. W 1814 r. powołany na członka Komitetu Cywilnego Reformy objął funkcję prezesa Sekcji Sądowej, w której opowiadał się za natychmiastowym uchyleniem francuskich kodeksów i zastąpieniem ich narodową kodyfikacją opartą na dawnym prawie polskim.

53 Zobacz przyp. 19.

54 Józef Szczepan Koźmian (1773-1831) - w 1809 r. został powołany na kierownika Wydziału Spraw Duchownych Rządu Centralnego obojga Galicji, jako jedyny duchowny wszedł w skład Komitetu Cywilnego Reformy, angażował się głównie w prace Sekcji Edukacji i Duchowieństwa. W Królestwie Polskim był członkiem Komisji Rządowej Wyznań Religijnych i Oświecenia Publicznego.

55 Mikołaj Andrzej Horodyski (1773-zm. ok. poł. XIX w.) - działacz Towarzystwa Republikanów Polskich, w Księstwie Warszawskim urzędnik średniego szczebla, w trakcie powstania listopadowego prezes Izby Obrachunkowej, minister spraw zagranicznych.

56 M. Zarychta, Propozycje ustrojowe Adama Jerzego Czartoryskiego i jego otoczenia (1813-1815), „Przegląd Historyczny” 2006, t. 97, z. 4, s. 495.

57 H. Grynwaser, Kodeks..., s. 71. 
szczytowy punkt aktywności ziemiańskich konserwatystów, moment, w którym uzyskali oni możliwość wyjścia poza krytykę i sformułowania programu pozytywnego ${ }^{58}$.

Większość członków Komitetu legitymowała się już bogatym doświadczeniem $\mathrm{w}$ służbie publicznej. Wielu z nich uczestniczyło $\mathrm{w}$ pracach organizacyjnych i przedsięwzięciach reformatorskich głównie w czasach Księstwa Warszawskiego. Ponadto część tego środowiska - Ostrowski, Wawrzecki, Matuszewicz, Linowski, Grabowski, Bieńkowski czy też Szaniawski - rozpoczynała swoje kariery w życiu publicznym kraju jeszcze w dobie stanisławowskiej. Nabyli pierwsze doświadczenia w bezpośrednim zetknięciu z systemem prawa przedrozbiorowego, jakże odmiennym od odziedziczonego po zaborcach i Napoleonie, a który bezskutecznie usiłowano zreformować i skodyfikować w czasach stanisławowskich, łącząc polską tradycję ideową $\mathrm{z}$ uniwersalnymi założeniami filozofii oświecenia. Żaden jednak z członków Komitetu nie był bezpośrednio zaangażowany w prace kodyfikacyjne prowadzone w XVIII w. ${ }^{59}$

Komitet zapoczątkował swoje obrady 4 lipca 1814 r., a więc jeszcze przed kongresem wiedeńskim, a tym bardziej przed ostateczną decyzją mocarstw co do przyszłych losów ziem polskich. Dlatego też w ukazie cesarskim mowa była tylko „o poprawie wewnętrznych urządzeń Księstwa Warszawskiego", a nie o tworzeniu nowego porządku prawno-państwowego. Zebrania odbywały się cyklicznie - zgodnie z regulaminem Komitetu - dwa razy w tygodniu nieprzerwanie aż do 18 czerwca 1815 r., kiedy to po ogłoszeniu o utworzeniu Królestwa Polskiego z woli Czartoryskiego prace Komitetu po odbyciu 92 posiedzeń zostały bezterminowo zawieszone ${ }^{60}$.

Podstawowe kwestie organizacyjne i plan działań Komitetu zostały ustalone na drugiej i trzeciej sesji 7 i 8 lipca. Wówczas też dokonano podziału Komitetu na cztery sekcje: Administracyjną, Skarbową, Edukacyjną i Duchowieństwa oraz Sekcję Sądową (zwaną także Sekcją Ustawodawczą bądź Prawodawczą). Była ona odpowiedzialna za reformę prawa sądowego w zakresie nie tylko prawa cywilnego i procedury, ale również ustroju sądów oraz prawa karnego, którym finalnie jednak się nie zajęła ${ }^{61}$. Zakres i kierunek prac sekcji wyznaczany był na posiedzeniach plenarnych Komitetu, co znalazło swoje odzwierciedlenie w jego Ordynacji wewnętrznej, w której przyjęto, że: „w wypracowaniu każdego szczegółowego przedmiotu żadna sekcja oddalać się nie może od ogólnych zasad przez Komitet sobie wskazanych" ${ }^{2}$. Sekcje odgrywały więc rolę służebną względem Komitetu i formalnie przynajmniej nie posiadały większej autonomii działania.

58 M. Mycielski, ,,Miasto ma mieszkańców, wieś obywateli”. Kajetana Koźmiana koncepcje wspólnoty politycznej (do 1830 roku), Wrocław 2004, s. 133.

59 Kodeks Stanistawa Augusta. Zbiór dokumentów, wyd. S. Borowski, Warszawa 1938, s. 22.

60 Czartoryski po dziewięciomiesięcznej nieobecności, przybywszy na ostatnie posiedzenie Komitetu Cywilnego Reformy 18 czerwca, uzasadniał powody zawieszenia dalszej jego działalności „zmianą Rządu Tymczasowego, [która] ma w tych dniach nastąpić, a wielu członków z Komitetu jest użytych do składu nowego rządu. Przeto [argumentował Książę] zwyczajne posiedzenia komitetowe nie mogą na teraz ciągle w przeznaczonych na posiedzenie dniach odbywać się, a jeżeliby kiedy tego potrzeba wypadła, to by członkowie dla odbycia posiedzenia uwiadomieni zostaną”, BKC, sygn. 5241 IV, s. 121. Protokół z tego posiedzenia nie zachował się w aktach Komitetu wraz z innymi protokołami.

61 BKC, sygn. 5233 IV, k. 15.

62 Ibidem, k. 9. 
Spośród członków Komitetu do Sekcji Sądowej weszli Franciszek Grabowski, Antoni Bieńkowski oraz Józef Kalasanty Szaniawski. Ciekawe natomiast i zastanawiające, że do Sekcji Sądowej nie wszedł Tomasz Wawrzecki, mimo że podówczas pełnił funkcję „dyrygującego” ministerium sprawiedliwości z ramienia Rady Najwyższej Tymczasowej, której zarazem był członkiem.

Prezydencja w Sekcji Sądowej przypadła Franciszkowi Grabowskiemu, zgodnie z uchwaloną przez Komitet zasadą, iż pozostawać on będzie ,zawsze przy członku Komitetu podług porządku nominacją najwyższą oznaczonego". Nazwisko Grabowskiego znalazło się bowiem w załączonej do ukazu monarszego liście członków powołanych do Komitetu wyżej aniżeli Bieńkowskiego i Szaniawskiego. Nie miał on jednak z tego tytułu żadnych szczególnych uprawnień, jak ustalono bowiem w Organizacji wewnętrznej Komitetu, rolą prezydującego każdej sekcji było jedynie „niezwłoczne uwiadamianie” Komitetu „o organizacji jej wewnętrznej oraz o rozpoczęciu dzieła, w ciągu którego na każdym z posiedzeń [...] winien [on był] dawać szczegółowe uwiadomienie o dalszych postępach jego" ${ }^{\prime 3}$.

Urodzony w 1750 r. Franciszek Grabowski był doświadczonym palestrantem lubelskim praktykującym jeszcze w czasach stanisławowskich jako mecenas, a następnie deputat na Trybunał Koronny. Natomiast w epoce porozbiorowej, jako osoba blisko związana z ordynatem Stanisławem Zamoyskim, został w 1809 r. radcą Wydziału Sprawiedliwości Rządu Centralnego obojga Galicji. Następnie, po przyłączeniu Galicji Zachodniej do Księstwa Warszawskiego, mianowano go radcą stanu i wszedł do Sekcji Sprawiedliwości Rady Stanu. Bliski mu światopoglądowo Kajetan Koźmian uważał Grabowskiego za przedstawiciela ostatniej generacji ,doskonałych, biegłych prawników w ustawach dawnej Polski”" ${ }^{\prime 4}$. Zarazem też Grabowski dał się poznać jako zadeklarowany przeciwnik obcych francuskich urządzeń ustrojowo-prawnych Księstwa, opowiadając się za podjęciem prac nad narodową kodyfikacją opartą na dawnym prawie polskim. Nieustannie dawał temu wyraz w toku prac Komitetu Cywilnego Reformy, angażując się nie tylko na polu reformy prawa sądowego, ale również sprzeciwiając się utrzymaniu biurokratycznej administracji, kosztem rezygnacji z planów przywrócenia klasycznie republikańskiego zarządu wzorowanego na organizacji komisji porządkowych z czasów stanisławowskich ${ }^{65}$. Cytowany Kajetan Koźmian w swych pamiętnikach charakteryzował Grabowskiego jako jednego z tych ekstrawaganckich tradycjonalistów, którzy „,jeszcze strój narodowy polski zachowali” $i$ „,nawet [...] golone głowy zatrzymali” ${ }^{\prime 66}$. Po utworzeniu Królestwa Polskiego Franciszek Grabowski nadal uczestniczył w przygotowaniu reformy prawa sądowego, skupiając się głównie na opracowaniu nowej organizacji sądownictwa. Nie brał natomiast udziału w pracach zmierzających do przygotowania konstytucji Królestwa Polskiego (wzmianka - umieszczona w relacji pamiętnikarskiej Antoniego Ostrowskiego - o tym, że wchodził on jakoby w skład tzw. Komitetu

63 Ibidem, k. 10.

64 K. Koźmian, Pamiętniki, t. II, Warszawa 1972, s. 225.

65 M. Gałędek, Koncepcje..., s. 407-410.

66 K. Koźmian, Pamiętniki, s. 242. 
Konstytucyjnego, jest fałszywa ${ }^{67}$ ). Grabowski dożył sędziwego wieku, umierając dopiero po upadku konstytucyjnego Królestwa w 1836 r.

Nieco młodszym reprezentantem tego samego pokolenia był urodzony w $1760 \mathrm{r}$. Antoni Bieńkowski. Cieszący się dużym autorytetem prawnik pełnił w czasach Księstwa Warszawskiego funkcję sędziego Sądu Apelacyjnego, którą piastował również w Królestwie Polskim. Powołany do Komitetu Cywilnego Reformy Bieńkowski od samego początku wyróżniał się zarówno swoją aktywnością na polu reformy prawa sądowego, jak i umiarkowanym stanowiskiem w ocenie francuskiego prawodawstwa ${ }^{68}$. Nieustannie też ścierał się z Grabowskim jako rzecznikiem radykalnego i bezwarunkowego odejścia od prawa francuskiego na rzecz restytucji porządku opartego na dawnych prawach polskich. Już na forum Komitetu po początkowej ofensywie skrajnych tradycjonalistów - w której wiodły prym pomysły Grabowskiego - przeważać zaczęły koncepcje bardziej umiarkowane. Ich głównym propagatorem w odniesieniu do prawa sądowego był właśnie główny adwersarz Grabowskiego - Antoni Bieńkowski. Trend, zarysowujący się u schyłku 1814 r., który finalnie zmierzał do tego, aby jeśli już prawo francuskie musiało zostać uchylone, to stało ono się wraz z innymi nowoczesnymi kodeksami głównym źródłem inspiracji dla kodyfikacji narodowej, rok później, w przededniu nadania konstytucji, zdawał się już dominować. Znalazło to swoje odzwierciedlenie w opiniach Jana Wincentego Bandtkiego i Antoniego Wyczechowskiego. Działając na zlecenie ks. Adama Jerzego Czartoryskiego, pod koniec 1815 r. sporządzili oni memoriały mające istotne znaczenie dla rekonstrukcji poglądów progresywnej elity prawniczej, która właśnie w tym momencie na trwałe już dyskontowała swoją przewagę nad nurtem tradycjonalistycznym. Odmiennie niż Bieńkowski występujący w Komitecie zaledwie rok wcześniej Bandtkie i Wyczechowski nie wahali się już otwarcie bronić uniwersalnej wartości kodeksów francuskich ${ }^{69}$. Ich memoriały zostały sformułowane w ramach działalności tzw. Komisji Kodeksowej, poniekąd następczyni Sekcji Sądowej Komitetu Cywilnego Reformy, powołanej mocą uchwały Rządu Tymczasowego z 25 września $1815 \mathrm{r}$.

Symptomatyczne jest, że na przewodniczącego tejże Komisji powołany został także Antoni Bieńkowski, nie zaś dawny prezes Sekcji Sądowej, Franciszek Grabowski, który w nominacjach do tego kolegium w ogóle został pominięty. Wprawdzie w następnych latach obaj nadal aktywnie uczestniczyli w pracach nad reformą prawa sądowego, ale tak jak rola Grabowskiego uległa pewnej marginalizacji i ograniczeniu jego zadań do przygotowania reformy ustroju sądowego, tak Bieńkowski w przygotowaniach reformy prawa prywatnego nadal odgrywał pierwszoplanową rolę, łącząc przez cały okres konstytucyjny (Bieńkowski zmarł w 1834 r.) swoją pracę z obowiązkami sędziego apelacyjnego,

67 A. Ostrowski, Żywot..., s. 505; M. Gałędek, Zagadka projektu Platera. Próba rekonstrukcji pierwszej fazy prac nad Ustawa konstytucyjna z 1815 r. [w:] Księga Jubileuszowa z okazji siedemdziesięciolecia urodzin oraz czterdziestopięciolecia pracy naukowej Pana Profesora Andrzeja Szmyta, red. P. Uziębło i in., Gdańsk [w druku].

68 Por. S. Askenazy..., s. 375; H. Grynwaser, Kodeks..., s. 70.

69 W. Sobociński, Jan Wincenty Bandtkie obrońca Kodeksu Napoleona (Przyczynki biograficzno-naukowe i memoriat z 1815 r.), ,Rocznik Lubelski” 1960, nr 3, s. 168-169; M. Gałędek, A. Klimaszewska, A Controversial Transplant..., s. 281-294; P.Z. Pomianowski, Postulat narodowego charakteru prawa w pracach kodyfikacyjnych doby Królestwa Kongresowego, CPH, 2019, t. 71, z. 1, s. 113-125. 
Udział trzeciego członka Sekcji Sądowej, Józefa Kalasantego Szaniawskiego, w jej pracach był niewielki. Szaniawski, urodzony w 1764 r., określany był przez Kajetana Koźmiana mianem „dawnego prawnika w Polsce [...] używającego reputacji filozofa niemieckiego" ${ }^{70}$. W Księstwie Warszawskim pełnił funkcję prokuratora generalnego przy Sądzie Kasacyjnym. Stąd jego udział w Sekcji Sądowej wydawał się ze wszech miar uzasadniony. Był też bardzo aktywny w pierwszych miesiącach działalności Komitetu, sporządzając m.in. projekt jego Organizacji wewnętrznej, przyjęty na drugiej sesji 7 lipca $1814 \mathrm{r}^{71}$ Wkrótce jednak, we wrześniu, wyjechał z kraju i towarzyszył Czartoryskiemu podczas obrad kongresu wiedeńskiego. Były jakobin i członek Towarzystwa Republikanów Polskich dokonał wolty światopoglądowej. Jak to barwnie ujął Hipolit Grynwaser, pod okupacją rosyjską Szaniawski zdołał „przedzierzgnąć się ostatecznie w zapalonego służalca wielkoszlacheckiej opinii konserwatywnej" "72. W konsekwencji opowiedział się jednoznacznie przeciwko dorobkowi francuskiemu, żądając powrotu do tradycyjnych wartości i rozwiązań instytucjonalnych. Znalazło to swoje odzwierciedlenie przede wszystkim w pracach, jakie rozwinął w ramach Sekcji Edukacji i Duchowieństwa, której przewodniczył, czy też w przygotowanym przez niego referacie wymierzonym w zbiurokratyzowaną administrację Uwagi o projekcie reformy administracji krajowej w bytym Królestwie Polskim ${ }^{73}$. Można więc przypuszczać, że dalsza obecność Szaniawskiego w pracach Komitetu wzmocniłaby siłę oddziaływania tradycjonalistów także na sferę prawa sądowego. W dobie Królestwa Polskiego Szaniawski (zmarły dopiero w 1843 r.) odszedł już definitywnie od prac nad reformą wymiaru sprawiedliwości, ogniskując swoją uwagę na przebudowie systemu oświatowego kraju.

Zgodnie z opracowanym przez Szaniawskiego regulaminem Komitet mógł przybrać do pomocy także inne osoby spoza swego grona ${ }^{74}$. Na tej podstawie do Sekcji Sądowej powołano grono wybitnych prawników Księstwa Warszawskiego w osobach: prokuratora Sądu Kasacyjnego Jana Nepomucena Wolickiego, księdza Franciszka Ksawerego Bohusza, sędziów apelacyjnych Jana Kantego Borakowskiego i Tadeusza Skarżyńskiego, mecenasa Sądu Kasacyjnego Kajetana Kozłowskiego oraz profesora Szkoły Prawa i notariusza, a w nieodległej przyszłości (od 1816 r.) Dziekana Wydziału Prawa i Administracji Uniwersytetu Warszawskiego, Jana Wincentego Bandtkiego ${ }^{75}$.

Zgodnie z treścią Ordynacji wewnętrznej: „Członkowie do składu osobnych sekcji z zewnątrz przybrani znajdować się powinni na posiedzeniu Komitetu, gdy tam projekt ich Sekcji do roztrząśnięcia przypadnie. Mają wtedy głos doradczy, a opinia większej ich liczby stanowi zawsze jedną kreskę w Komitecie" ${ }^{76}$. Jednakże z protokołu obrad Komitetu nie wynika, aby któryś z przybranych członków wziął udział w jakimkolwiek

70 K. Koźmian, Pamiętniki, s. 288.

71 BKC, sygn. 5233 IV, k. 8v.

72 H. Grynwaser, Kodeks..., s. 69. Hipolit Grynwaser w ten sam sposób scharakteryzował także Andrzeja Horodyskiego, ale analiza treści protokołów wskazuje, że reprezentował on bardziej umiarkowane stanowisko.

73 Biblioteka im. Zielińskich Towarzystwa Naukowego Płockiego, sygn. 502, k. 1 i n.; M. Gałędek, Wplyw wojen napoleońskich na wzrost antagonizmu do biurokracji w polskiej myśli administracyjnej, ,Studia z Dziejów Państwa i Prawa Polskiego" 2019, t. 22 [w druku].

74 BKC, sygn. 5233 IV, k. 10.

75 Ibidem, k. 16.

76 Ibidem, k. 11. 
posiedzeniu plenarnym. Można też mieć wątpliwości, czy w ogóle włączyli się oni aktywnie w prace Sekcji. Nie posiadamy bowiem żadnych informacji o zaangażowaniu się w prace nad reformą przeprowadzaną przez Komitet Bandtkiego, Borakowskiego, Bohusza i Kozłowskiego. Odnotować jednakże wypada pewne braki w materiale źródłowym z zakresu przebiegu prac w sekcjach Komitetu. W szczególności nie zachowały się protokoły z obrad Sekcji Sądowej, o których istnieniu wspomina protokół obrad plenarnych. Dowiadujemy się z niego, iż takowe protokoły ,podawane były do głosowania każdemu jej członkowi tak z przytomnych [tj. obecnych] na posiedzeniu, jako też przesłane nieprzytomnym".

Natomiast w protokole obrad plenarnych Komitetu pojawia się jedna wzmianka o sędzim apelacyjnym Tadeuszu Skarżyńskim jako o autorze „projektu obejmującego pierwsze zasady organizacji sądowej, które wyjął z woluminów praw polskich i poczynił w nich niektóre odmiany i dodatki, do czasu i obecnych okoliczności stosowne". Już 4 sierpnia „po dokładnym namyśle i roztrząśnięciu” został on przyjęty z niektórymi jeszcze odmianami” w Sekcji Sądowej i wniesiony do decyzji Komitetu przez Grabowskiego ${ }^{77}$.

$\mathrm{Z}$ pewnością natomiast $\mathrm{w}$ prace prowadzone przez Komitet zaangażował się Jan Nepomucen Wolicki, jako aktywny pomocnik Franciszka Grabowskiego w Sekcji Sądowej, podobnie jak innego swego krajana - Stanisława Zamoyskiego. Wolicki, choć niższego nieszlacheckiego stanu, mógł być zresztą blisko związany z Grabowskim jeszcze w epoce przedrozbiorowej. Urodzony w $1766 \mathrm{r}$. Wolicki był wprawdzie kilkanaście lat młodszy od niego, ale rozpoczynał swoją karierę prawniczą w tym samym Trybunale Koronnym, przy którym działał Grabowski, jako pisarz dekretowy Trybunału, a następnie pisarz trybunalski. Znalazł się również w Rządzie Centralnym Obojga Galicji, na którego czele stał Zamoyski. Został w nim najpierw radcą wydziałowym, później zaś komisarzem rządowym. W 1809 r. Wolickiego wybrano z kolei deputowanym na Sejm i członkiem Komisji Skarbowej, zaś w 1811 r. został mianowany sędzią apelacyjnym, a później prokuratorem przy Sądzie Kasacyjnym. Znał więc dobrze zarówno Bieńkowskiego, jak i Szaniawskiego ${ }^{78}$. Także w okresie konstytucyjnym Królestwa Polskiego Wolicki, zmarly dopiero w 1847 r., aktywnie włączył się w prace nad reformą prawa sądowego.

Wyznacznikiem dla kierunku prac Komitetu w odniesieniu do reformy prawa sądowego był artykuł 2: „Le Code Napoléon civil et de procédure judiciaire devrait être aboli le plus tôt possible. On pourrait intérimalement y substituer les lois polonaises, le Statut de Lithuanie, ainsi que les formes judiciaires usitées avant l'introduction de la procédure française. Le Comité discutera si les codes doivent être abolis entiérement ou en partie, et à quelle époque cette abolition pourrait avoir lieu. Il proposera aussi un plan et la composition d'une Commission séparée à créer qui sera chargée de la rédaction d'un nouveau Code civil, criminel et de procédure, de même que l'organisation définitive de l'ordre judicaire [...]"’79. Cesarz - cytując memoriał Czartoryskiego z lutego 1814 r. - zlecił Komitetowi przygotowanie gruntu do zmiany obowiązującego porządku prawnego po-

77 Ibidem, k. 56-57.

78 Ibidem, k. 282.

79 Tłumaczenie zarówno tego punktu, jak i całego pisma cesarza określającego zadania Komitetu znajduje się w części I publikowanych materiałów źródłowych. 
przez uchylenie francuskich kodeksów cywilnego i procedury cywilnej i zastąpienie ich kodyfikacją o charakterze narodowym (z tymczasowym przynajmniej wykorzystaniem dawnego prawa polskiego i III Statutu litewskiego ${ }^{80}$. Zgodnie z interpretacją woli cesarskiej, dokonaną przez samych członków Komitetu, mieli oni za zadanie określić, które części Kodeksu Napoleona wymagają natychmiastowego zastąpienia ,prawem narodowym", i w tym zakresie przystąpić do opracowania projektów ustaw nowelizacyjnych ${ }^{81}$.

Żaden z projektów Komitetu, nie tylko tych dotyczących prawa sądowego, nie stał się obowiązującym prawem. Oceniając dorobek Komitetu, najlepiej chyba posiłkować się krytycznymi opiniami samych jej członków. I tak Andrzej Horodyski 10 listopada 1815 r., czyli pół roku po bezterminowym zawieszeniu prac, wskazał, że: „Całe [...] dzieło Komitetu Cywilnego było raczej skutkiem radości z zapowiedzianej odmiany rzeczy krajowych na lepsze, jak [z] zimnej rozwagi i powstało [...] z gorliwej niecierpliwości, aby czym prędzej dobrze krajowi było, która niecierpliwość nie dała nawet sobie czasu zebrać wprzódy potrzebnych do przedsięwzięcia tej pracy pomocy i materiałów [...] nie rozpoznała wprzódy stanu rzeczy krajowych, lecz usiłowała pracować nad jego całkowitą reformą, stosownie do własnych natchnień i faktów z zawodnej pamięci czerpanych" "82. Także dla Czartoryskiego roczna działalność Komitetu jawiła się jako zebrania „kilku osób”, na których „dyskutowano sposoby urządzenia różnych części administracji, ale te schadzki mało albo nic nie wydały, to tylko chyba, że się materie rozbierały i porządkowały" ${ }^{\prime 3}$.

Czy oznaczało to, że dorobek Komitetu nie miał dla przyszłych członków rządu Królestwa Polskiego żadnej wartości? Byłby to za daleko posunięty wniosek, o czym świadczy podejście do niego władz tymczasowych Królestwa w drugiej połowie $1815 \mathrm{r}$. Powołana w tym czasie Rada Stanu latem tego roku postanowiła utworzyć „komisję”, w skład której weszło dwóch aktywnych członków Komitetu: Tadeusz Matuszewicz i Aleksander Linowski, a także Kajetan Koźmian. Zostali oni zobowiązani do przygotowania programu mającego na celu opracowanie projektów „praw organicznych” dla Królestwa Polskiego, czyli niejako zadecydowania o sposobie kontynuacji prac prowadzonych wcześniej przez Komitet, w szczególności zaś m.in. do „przygotowania rozbioru materii” przezeń już „wypracowanych" ${ }^{44}$. Matuszewicz, Linowski i Koźmian, składając 2 września swój raport, zarekomendowali możliwość wykorzystania „dzieła” Komitetu $^{85}$. Jego spuściznę należało jednak podzielić na materie, które ,już przyjęły wszelką dokładność i przygotowanie do deliberacji”, oraz na te, które „do pewnego stop-

80 Zadania Komitetu wyszczególnia J. Przygodzki, Rada ..., s. 179.

81 BKC, sygn. 5233 IV, k. 14, 17-18, 197.

82 Biblioteka Naukowa PAN i PAU w Krakowie, sygn. 152, cz. 1, s. 93.

83 BKC, sygn. 5242 V, s. 343-344.

84 Rzad Tymczasowy do Rady Stanu, 28 lipca 1815 [w:] J. Bojasiński, Rządy..., s. 264-265; M. Gałędek, Koncepcje..., s. 129-130. Paradoks sytuacji polegał jednak na tym, że członkowie komisji nie uzyskali dostępu do materiałów Komitetu Cywilnego Reformy i ,kiedy mimo wszelkich starań niepodobną było rzecz pozyskać udzielenia dzieła komitetowego, gdy dotąd po sekcjach rozrzucone i w redakcji nieukończone nie odebrało porządnego kształtu”, komisja zmuszona była poprzestać „na krótkich wyciągach z protokołów [...] pod jeden widok zebranych”, wspierając się ,zawodną pamięcią w odsuniętych kilkumiesięcznym przeciągiem czasu przedmiotach". W tej sytuacji autorzy raportu nie byli „w stanie innego dać [...] wyobrażenia, jak ogólne i dzielić inaczej materie [...] jak na te, które co do zasad swoich ugodzonymi zostały, i na te, do których projekty tylko przysposobione przez żadną rozwagę nie przeszły”. BKC, sygn. 5262 IV, s. 58-59.

85 Ibidem, s. 60. 
nia posunięte wzywają [do] rozpoczęcia przerwanej nad sobą pracy" ${ }^{\text {"6 }}$. Prace kodyfikacyjne zostały zaliczone do tej drugiej grupy. Na podstawie opinii wyżej wspomnianej komisji Rząd Tymczasowy 25 września podjął uchwałę o powołaniu właściwej Komisji Kodeksowej do kontynuowania dzieła reformy prawa sądowego wraz z poleceniem, aby „,za pierwszą osnowę deliberacji” służyły tej ostatniej (podobnie jak pozostałym komisjom utworzonym na mocy tej samej uchwały) „materiały przez Komitet Cywilny [Reformy] przysposobione”. Rząd zaznaczył wręcz, iż „,wielka część rzeczonej pracy, przez Komitet Cywilny [została już] przygotowana [i] nie potrzebuje [niczego więcej] jak tylko przedstawienia do ostatecznej w Radzie Stanu deliberacji" ${ }^{\prime 87}$.

Dzieło Komitetu nie zostało więc formalnie odrzucone i stać się mogło ważnym punktem odniesienia i źródłem inspiracji w toku dalszych prac nad kodyfikacją narodową dla Królestwa Polskiego. Kwestia ta jest jeszcze przedmiotem badań prowadzonych przez edytorów niniejszej publikacji. Nie siląc się zatem na formułowanie przedwczesnych wniosków, można jednak postawić tezę, że wpływ prac Komitetowych na późniejsze prace był tym silniejszy, im trwalsze piętno na przyszłych projektach zdołali odcisnąć: z jednej strony Antoni Bieńkowski, z drugiej - tradycjonaliści w osobie Franciszka Grabowskiego, a także jego głównego pomocnika - Jana Nepomucena Wolickiego. Szczególnie Bieńkowski - w związku z opisanym już zwycięstwem nurtu progresywnego nad tradycjonalistycznym w konstytucyjnym Królestwie Polskim - miał okazję wyzyskać swój dorobek, doświadczenie i autorytet, wpływając pośrednio bądź bezpośrednio na przebieg prac projektowych prowadzonych po $1815 \mathrm{r}$.

Do druku podajemy wybór dokumentów związanych z działalnością Komitetu Cywilnego Reformy w zakresie prawodawstwa oraz organizacją samego Komitetu oraz fragmenty protokołów obrad Komitetu Cywilnego Reformy dotyczące tych dokumentów:

1. Rozkaz z własnoręcznym Najjaśniejszego Aleksandra Cesarza Wszech Rosji podpisem stanowiący Komitet do przygotowania projektów względem poprawy wewnętrznego urządzenia kraju Księstwa Warszawskiego ${ }^{88}$ (ukaz carski upoważniający Czartoryskiego, Nowosilcowa i Wawrzeckiego do zwołania człon-

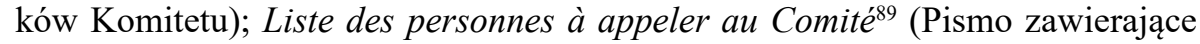
nominacje członków Komitetu ${ }^{90}$ ); Objets dont le Comité doit s'occuper ${ }^{91}$ (Pismo

86 Ibidem, s. 57-58.

87 Uchwała Rządu Tymczasowego, 25 września 1815 [w:] J. Bojasiński, Rządy..., s. 265.

88 BKC, sygn. 5236 IV, s. 9. Tytuł za Wykazem pism wystawionych w Komitecie Cywilnym Reformy sporządzonym przez D. Rostkowskiego (1800-1881), bibliotekarza Czartoryskich, odpowiedzialnego m.in. za konserwację rękopisów. Informację, że to on sporządził spisy i przygotował dokumenty do oprawy w połowie XIX w., podano w: Katalog rękopisów Biblioteki Książat Czartoryskich w Krakowie. Sygnatury 5214-5319, oprac. J. Pezda, Kraków 2001, s. 65. Dokument nie posiada oryginalnego tytułu.

89 BKC, sygn. $5236 \mathrm{IV}$, s. 9; tytuł oryginalny.

90 Tytuł wg spisu D. Rostkowskiego. Przekład tytułu francuskiego powinien brzmieć: „Lista osób, które należy powołać do Komitetu".

91 BKC, sygn. 5236 IV, s. 9, 10-13; tytuł oryginalny. 
obejmujące w sobie przedmioty Komitetowi poruczone ${ }^{92}$ ); Ordynację wewnętrzną Komitetu ${ }^{93}$;

2. Myśli JW. Prezydującego Nowosilzoff względem podziału prac Komitetu na sekcje $^{94}$

3. [Projekt] w miejsce tytułu 5 księgi 1 Kodeksu Francuskiego Cywilnego ${ }^{95}$ (obejmuje prawo osobowe małżeńskie);

4. [Projekt] w miejsce tyt. 5 księgi 3 Kodeksu Cywilnego Francuskiego ${ }^{96}$ (obejmuje prawo małżeńskie majątkowe);

5. Pismo księdza Dhiela Intendenta Generalnego Zborów Ewangelickich Reformowanych względem ustaw małżeńskich i rozwodów ${ }^{97}$;

6. Wstęp przy wprowadzeniu planu do kodeksu cywilnego ${ }^{98}$;

7. Plan czyli prospekt do kodeksu cywilnego ${ }^{99}$;

8. Projekt do uformowania Komisji mającej wygotować Księgę prawa cywilnego i procedury ${ }^{100}$;

9. Procedurę Sądownictwa Cywilnego Pierwszej Instancji ${ }^{101}$;

10. Wstęp przy wprowadzeniu na dniu 29tym grudnia 1814 Planu Kodeksu Postępowania $^{102}$;

11. Prospekt Kodeksu Postępowania Sądowego ${ }^{103}$.

Wymienione dokumenty zawarte są w woluminie należącym do Muzeum Narodowego w Krakowie - Oddział Biblioteka Książąt Czartoryskich, o sygnaturze 5236 IV, zatytułowanym: „Papiery Komitetu Reformy co do ogólności, administracji wewnętrznej, prawodawstwa i sądowości, materii skarbowej, duchowieństwa i edukacji i korespondencji z Komitetem Wojskowym". Na tom składają się 694 numerowane strony. W numeracji zdarzają się błędy. Tom zawiera spis treści sporządzony przez Daniela Rostkowskiego. Materiał ten został zmikrofilmowany ${ }^{104}$. To samo Muzeum dysponuje „Protokołem posiedzeń Komitetu Reformy od jego rozpoczęcia się dnia 4 lipca 1814”. Jest to oprawny tom o objętości 560 stron, któremu nadano sygnaturę 5233 IV. To nakreślony jedną ręką czystopis, na który składają się protokoły 91 posiedzeń (4 lipca 1814 - 15 czerwca

92 Tytuł wg spisu D. Rostkowskiego. Przekład tytułu francuskiego powinien brzmieć: „Przedmioty, którymi Komitet winien się zająć".

93 Ibidem, s. 25-28. Dokument tak został określony w protokole - BKC, sygn. 5233 IV, s. 9.

94 BKC, sygn. 5236 IV, s. 9, 17-24. Tytuł wg spisu D. Rostkowskiego. Dokument nie posiada oryginalnego tytułu.

95 BKC, sygn. 5236 IV, s. 255-275. Rostkowski potraktował ten i kolejny projekt jako całość wraz z Projektem artykułów do zniesienia i zmiany niektórych kodeksowych czéści i zatytułował: Projekt tegoż [Antoniego Bieńkowskiego] w sekcji sądowej roztrząśniony zawierający odmiany niektórych części kodeksu cywilnego o matżeństwie i majątkowych umowach matżonków.

96 BKC, sygn. 5236 IV, s. 275-283

97 Ibidem, s. 371-379.

98 Ibidem, s. 287-295.

99 Ibidem, s. 299-320.

100 Ibidem, s. 355-358.

101 Ibidem, s. 411-418.

102 Ibidem, s. 323-331.

103 Ibidem, s. 332-348.

104 W Bibliotece Narodowej w Warszawie stosownemu mikrofilmowi nadano sygnaturę 23815. 
$1815)^{105}$. Także ten wolumin został zmikrofilmowany ${ }^{106}$. Oba woluminy są napisane starannym ówczesnym polskim językiem urzędowym. Sporadycznie pojawiają się słowa obce (łacińskie i francuskie) - czasem bezpośrednio w tekście, a czasem w nawiasach. Stosunkowo nieliczne dokumenty zostały sporządzone w całości po francusku - kiedy dokumenty te przytaczano in extenso w protokołach, nie dokonywano thumaczenia.

Wybraliśmy dokumenty, które wiązały się z przygotowaniami czynionymi przez Komitet Cywilny Reformy zmierzającymi do uchylenia francuskich kodeksów - cywilnego i procedury cywilnej i zastąpienia ich regulacjami mającymi charakter „narodowy”. Seria tychże źródeł poprzedzona została publikacją dokumentów określających zakres zadań i zasady organizacji pracy w Komitecie, a w szczególności w jego Sekcji Sądowej jako komórce bezpośrednio odpowiedzialnej za prace nad przygotowaniem reformy prawa sądowego. Ograniczenia publikacyjne spowodowały, że z jednej strony wydane zostały jedynie te źródła, które w założeniu miały służyć przygotowaniu przyszłej kodyfikacji, a pominięte te, których celem miało być tylko czasowe rozwiązanie doraźnych problemów związanych ze stosowaniem prawa cywilnego i procedury. Z tego względu pominięte zostały dyskutowane w Komitecie dokumenty dotyczące (1) „ułatwienia spraw konkursowych”, (2) „oszacowania przez detaksatorów i wystawienia na publiczną licytację dochodów dóbr nieruchomych za dług egzekwowanych", (3) „zmniejszenia procentów wierzycielskich z czasu wojen, przedłużenia moratorium co do wypłaty kapitałów” i „przepisów względem tymczasowej egzekucji procentów” oraz (4) ,uchylenia iustitium". Z drugiej strony do niniejszego cyklu publikacyjnego nie weszły źródła dotyczące przygotowywanej przez Komitet nowej organizacji sądownictwa, która pozostawała w bliskim związku z reformą postępowania cywilnego.

Tekst został uwspółcześniony zgodnie z zasadami przewidzianymi w Instrukcji wydawniczej dla źródet historycznych od XVI do połowy XIX wieku (red. K. Lepszy, Wrocław 1953) ${ }^{107}$. Uwspółcześnialiśmy formy gramatyczne, nie ingerując jednak w źródłosłowy. Słowa, które mogłyby sprawić kłopot współczesnemu czytelnikowi (archaizmy, wyrazy obcojęzyczne), zaopatrzyliśmy w objaśniające je przypisy. Natomiast ukaz carski określający zadania Komitetu Cywilnego Reformy oraz Myśli prezydujacego Nowosilzoff względem podziału prac Komitetu na sekcje podajemy we francuskim oryginale oraz w tłumaczeniu na język polski. Zgodnie z pkt. 24 lit. b Instrukcji wydawniczej... upraszczamy listy obecności poprzedzające publikowane fragmenty protokołów (w szczególności pomijamy funkcje sprawowane przez poszczególnych członków Komitetu i informację, że posiedzenia odbywały się w Warszawie).

Edytując zawarte $\mathrm{w}$ materiałach Komitetu teksty francuskojęzyczne (rozkaz Aleksandra I oraz pismo Nowosilcowa), ograniczyliśmy się jedynie do uwspółcześnienia pisowni niektórych wyrazów (changemens - changements) oraz poprawienia oczywistych błędów ortograficznych (genèral - général). Poprawiona została również interpunkcja.

Ponadto zdecydowaliśmy się na wskazanie w przypisach fragmentów Volumina Legum cytowanych przez A. Bieńkowskiego. Odnalezienie w nich odpowiednich norm

105 Katalog...

106 Sygnatura Biblioteki Narodowej: 23807.

107 Kierowaliśmy się ponadto sugestiami M. Handelsmana zawartymi w recenzji wydawnictwa źródłowego obejmującego materiały Komisji Rządzącej („Kwartalnik Historyczny” 1921, R. 35, s. 160-167). 
jest znacznie trudniejsze niż w wypadku pozostałych źródeł, zwłaszcza że Bieńkowski często skraca, a czasem wręcz przeinacza tytuły konstytucji lub ich fragmentów ${ }^{108}$. (Zauważmy, że cytowanie tego źródła - zwłaszcza edycji oryginalnej - jest z natury rzeczy niełatwe, szczególnie gdy mamy do czynienia z aktami pozbawionymi jakichkolwiek jednostek redakcyjnych - nawet akapitów). Posłużyliśmy się edycją Jozafata Ohryzki. W przypisach podajemy tylko tom i stronę, na której dany akt się zaczyna. W kilku przypadkach nie udało się odnaleźć wskazanych fragmentów.

Kolejnym dokumentom oraz wyimkom z protokołów nadajemy numery (pogrubionymi cyframi arabskimi ponad dokumentem, wyśrodkowane). W nawiasach kwadratowych podajemy numery kolejnych stronic rękopisów (numer oznacza początek strony).

108 Kilka przykładów zaznaczono w przypisach. 


\section{Pierwsza część edycji: Organizacja i zadania Sekcji Sądowej [Ustawodawczej] oraz wstępne dyskusje nad planem reformy kodyfikacyjnej Komitetu Cywilnego}

Fragmenty protokołu posiedzeń Komitetu Cywilnego Reformy z sesji 1, 2, 3 i 4 obrad toczacych się od 4 do 10 lipca 1814 r. obejmujacych debatę o organizacji i zadaniach Komitetu, w tym jego Sekcji Sądowej (m.in. treść wciagniętych do protokołu pism „Liste des personnes à appeller au Comité”, „,Objets dont le Comité doit s'occuper” oraz „,Ordynacji wewnętrznej Komitetu”). Or. Biblioteka Książąt Czartoryskich, rkps, sygn. 5233 IV, Protokót posiedzeń Komitetu Reformy od jego rozpoczęcia się dnia 4 lipca 1814.

4 VII 1814

[s. 3]

\section{Sesja 1}

W Warszawie w domu Jaśnie Wielmożnego Ostrowskiego Senatora Wojewody i Prezesa Senatu Księstwa Warszawskiego.

Obecni Jaśnie Wielmożni i Wielmożni:

[Nikołaj] Nowosilcow Tajny Radca i Senator Imperii, Wiceprezes Rady Najwyższej Tymczasowej Księstwa Warszawskiego), Prezydujący,

[Tomasz] Wawrzecki Tajny Radca Imperatorski, i członek pomienionej Rady Najwyższej Tymczasowej dyrygujący ministerstwami sprawiedliwości i wojny,

[Tomasz] Ostrowski Wojewoda i Prezes Senatu Księstwa Warszawskiego, [Stanisław] Zamoyski Wojewoda, [Aleksander] Linowski Radca Stanu, [Andrzej] Horodyski Konsyliarz Głównej Izby Obrachunkowej, [Antoni] Bieńkowski Sędzia Apelacyjny, [Józef Kalasanty] Szaniawski były Prokurator Sądu Kasacyjnego.

Komitet zgromadził się na mocy Najwyższego Ukazu Jego Imperatorskiej Mości, który wraz z notami do niego przyłączonymi zawierają się w osnowie następującej:

J'autorise le Prince Adam Czartoryski, Mr Novossilzoff et Mr Wawrzecki de réunir les personnes nominées dans la note ci-jointe et même d'en appeler encore d'autres selon 
[s. 4] qu'ils le jugeront nécessaire pour préparer conjointement avec elles le travail des changements que je veux faire dans la Régie du Duché lors de mon passage par Varsovie. La série des objets qui doivent les occuper est marquée dans la même note.

Signé Alexandre ${ }^{1}$

Liste des personnes à appeler au Comité

Ostrowski Président du Sénat ${ }^{2}$

Zamoyski (l'Ordinat) Sénateur Palatin

Mostowski dernièrement Ministre de l'Intérieur du Duché

Matuszewicz dernièrement Ministre des Finances du Duché

Linowski Conseilleur d'Etat

Grabowski Conseiller d'Etat

Ossolinnski Président de la Cour d'Appel

l'Abbé Koźmian, Chanoine et Infulat

Horodyski, Conseiller de la Cour suprême des Comptes

Bieńkowski Juge à la Cour d'Appel

Kuczyński Dominique (le Staroste)

Szaniawski, ci-devant Procureur Général de la Cour de Cassation

Cette liste a été lue, et trouvée bonne pour la Majesté Impériale Paris le 19 Mai $1814^{3}$

\section{[s. 5] Objets dont le Comité doit s'occuper \\ 1}

Le système actuel de l'administration intérieure du Duché est oppressif et coûteux. Il convient de le remplacer par un autre qui soit mieux adapté au caractère national, aux habitudes et à la pauvreté du pays. Il semble que les anciennes commissions de bon ordre, les commissions civico-militaires, ainsi que les chambres d'administration, organisées en 1807 dans la Grande Pologne et en 1809 dans la ci-devant Galicie Occidentale, répondaient mieux à ce but, de même qu'à la simplicité, qui doit caractériser les affaires d'un pays agricole.

2

Le Code Napoléon civil et de Procédure judiciaire devrait être aboli le plus tôt possible. On pourrait intérieurement y substituer les lois polonaises, le statut de Lituanie, ainsi que les formes judiciaires usitées avant l'introduction de la procédure française. Le Comité discutera si les codes doivent être abolis entièrement ou en partie, et à quelle époque cette abolition pourrait avoir lieu. Il proposera aussi le plan et la composition d'une Commission séparée à créer, qui sera chargée de la rédaction [s. 6] d'un nouveau Code civil, criminel et de procédure, de même que de l'organisation définitive de l'ordre judiciaire.

1 Identyczny tekst „Rozkazu z własnoręcznym Aleksandra [...] pismem stanowiącym Komitet do przygotowania projektów względem poprawy wewnętrznego urządzenia kraju Księstwa Warszawskiego" - BKC, sygn. 5236 IV, s. 9.

2 Na liście zabrakło Tomasza Wawrzeckiego.

3 Identyczny tekst pisma ,zawierającego nominację członków Komitetu” - BKC, sygn. 5236 IV, s. 9. 
3

Réforme et diminution de la liste civile d'après les changements nouveaux dans l'administration du pays.

4

Mesures pour relever le bien-être et l'esprit public des villes. Le rétablissement de leurs anciens tribunaux ou magistrats judiciaires ainsi que des municipalités, joint à la restitution des fonds qui leur appartenaient, pourront y contribuer le plus. Embellissement de la Capitale. Protection et secours à accorder au Théâtre national. 5

Mesures à prendre pour améliorer le sort des paysans et de leur ouvrir des moyens d'acquérir progressivement une existence indépendante.

6

Projet d'un nouveau système de finances, coordonné avec le besoin de relever le commerce et l'agriculture.

7

Mesures pour rendre au Clergé sa [s. 7] considération, ainsi que des biens, et pour augmenter ses moyens d'être vraiment utile.

8

Mesures pour relever les lettres, l'Instruction publique et les différents établissements qui s'en occupent, nommément l'ancien Académie de Cracovie.

9

Garanties du droit sacré de propriété, contre toute atteinte des réquisitions arbitraires de quelque nature qu'elles soient.

La volonté de Sa Majesté Impériale est, qu'en général tous les changements et toutes les réformes dans le système actuel du Gouvernement du Duché s'opèrent avec le moins de précipitation possible, afin d'éviter les suites désastreuses de tout bouleversement subit. Cette note a été lue et trouvée bonne par Sa Majesté Impériale. Paris le 19 Mai 1814

\section{Ttumaczenie:}

Upoważniam księcia Adama Czartoryskiego, Pana Nowosilcowa i Pana Wawrzeckiego do zebrania osób powołanych załaczona nota, a nawet do dołaczenia innych [s. 4], jeśli uznaja to za konieczne, $w$ celu wspólnego przygotowania z nimi prac nad zmianami, które chcę wprowadzić w zarządzaniu Księstwem podczas mojego pobytu w Warszawie. Lista przedmiotów, którymi maja się zajmować, jest wyszczególniona w niniejszej nocie. Podpisano: Aleksander

Lista osób, które należy powołać do Komitetu

Ostrowski Marszatek Senatu

Zamoyski (Ordynat) Senator Wojewoda

Mostowski ostatnio Minister Spraw Wewnętrznych Księstwa

Matuszewicz ostatnio Minister Finansów Księstwa

Linowski Radca Stanu

Grabowski Radca Stanu

Ossoliński Prezes Sadu Apelacyjnego

Ojciec Koźmian, Kanonik i Infutat 
Horodyski, Sędzia Najwyższej Izby Obrachunkowej

Bieńkowski Sędzia Sąu Apelacyjnego

Kuczyński Dominik (starosta)

Szaniawski, wcześniej Prokurator Generalny przy Sądzie Kasacyjnym

Lista ta została przeczytana i zaaprobowana przez Jego Wysokość w Paryżu 19 maja $1814 r$.

[s. 5] Przedmioty, którymi ma zająć się Komitet

1

Obecny system administracji wewnętrznej w Księstwie jest uciązliwy i kosztowny. Należy go zastapić innym, lepiej dostosowanym do charakteru narodowego, zwyczajów i ubóstwa kraju. Wydaje się, że dawne komisje dobrego porzadku, komisje cywilno-wojskowe, a takze izby administracyjne, zorganizowane $w 1807 \mathrm{r}$. w Wielkopolsce $i w 1809 \mathrm{r}$. $w$ dawnej Galicji Zachodniej, lepiej odpowiadaty temu celowi, a także prostocie, która powinna być wlaściwa dla spraw państwa rolniczego.

2

Kodeks cywilny Napoleona i postępowania sadowego powinien zostać jak najszybciej zniesiony. Można by go wewnętrznie zastapić przepisami prawa polskiego, Statutem litewskim, a także formami sadowymi stosowanymi przed wprowadzeniem procedury francuskiej. Komitet omówi, czy kodeksy te powinny zostać zniesione w calości czy $w$ cześsi oraz $w$ jakim czasie powinno to nastapić. Zaproponuje również plan i skład osobnej Komisji, która będzie utworzona i odpowiedzialna za opracowanie [s. 6] nowego kodeksu cywilnego, karnego i kodeksu postepowania oraz ostatecznej organizacji sadownictwa.

3

Reforma i ograniczenie listy cywilnej zgodnie z nowymi zmianami w administracji kraju. 4

Działania majace na celu poprawe dobrobytu $i$ ducha publicznego $w$ miastach. Przywrócenie ich dawnych sądów lub sędziów oraz rad miasta, a także zwrot należacych do nich funduszy moga się do tego przyczynić w najwyższym stopniu. Upiększenie stolicy. Ochrona i pomoc, której należy udzielić Teatrowi Narodowemu.

5

Działania, które należy przedsięwziąć w celu poprawy losu chlopów i zapewnienia im środków do stopniowego uzyskania samodzielnej egzystencji.

6

Projekt nowego systemu finansów, skoordynowanego z potrzeba rozwoju handlu i rolnictwa.

7

Działania mające na celu przywrócenie duchowieństwu jego [s. 7] znaczenia, a także majątku, oraz zwiększenie jego środków, by mogło być naprawdę użyteczne. 8

Działania mające na celu rozwój nauk humanistycznych, edukacji publicznej i różnych instytucji, które się nimi zajmuja, w szczególności dawnej Akademii Krakowskiej. 
9

Zagwarantowanie świętego prawa własności, przeciwko wszelkim naruszeniom arbitralnych rekwizycji jakiegokolwiek rodzaju.

Wola Jego Wysokości Cesarza jest, by ogólnie wszystkie zmiany $i$ wszystkie reformy w obecnym systemie Rządu Księstwa zostały przeprowadzone z możliwie jak najmniejszym pośpiechem, aby uniknąc katastrofalnych skutków wszelkich nagłych zmian.

Niniejsza nota została przeczytana i zaaprobowana przez Jego Wysokość Cesarza. Paryż 19 maja 1814 r.

Jaśnie Wielmożny Nowosilcow przeczytał prócz tego list Jaśnie Oświeconego Księcia Czartoryskiego stosujący się do zamiarów, w jakich powyższy Komitet wyznaczonym został wskazujący [s. 8] oraz życzenia Jego Imperatorskiej Mości być dopełnionymi za przybyciem tego monarchy do Warszawy ${ }^{4}$.

Polecono Wielmożnemu Szaniawskiemu, członkowi Komitetu, ułożenie projektu ordynacji wewnętrznej, czyli sposobu postępowania tego Komitetu.

W ogólności członki jego wzięły na siebie obowiązek przynieść uwagi swoje nad przedmiotami wyżej onemu poleconymi.

Do trzymania pióra w Komitecie wezwano Jaśnie Pana Ignacego Szczurowskiego, Sekretarza Protokolistę Rady Ministrów [...]

7 VII 1814

[s. 8]

Sesja 2

W domu Jaśnie Wielmożnego Ostrowskiego Senatora Wojewody i Prezesa Senatu.

Z udziałem: Nikotaja Nowosilcowa jako prezydujacego, Tomasza Wawrzeckiego, Tomasza Ostrowskiego, Stanistawa Zamoyskiego, Aleksandra Linowskiego, Andrzeja Horodyskiego, Antoniego Bieńkowskiego i Józefa Kalasantego Szaniawskiego.

Oprócz pomienionych członków Komitetu znajdował się zaproszony Jaśnie Oświecony Książę Lubecki jako dyrygujący Ministerium Spraw Wewnętrznych, dla udzielenia potrzebnych objaśnień w rzeczach [s. 9] administracji krajowej.

Wielmożny Szaniawski wskutek danego sobie polecenia na pierwszej sesji wnosi przygotowany projekt Ordynacji wewnętrznej Komitetu, zawierający w sobie krótkie przepisy względem sposobu odbywania prac tegoż.

Takowy projekt po niektórych poprawkach zgodnie przyjęty i przez Jaśnie Wielmożnego Prezydującego zacyfrowany zamienia się w uchwałę, jak następuje.

Skutkiem najwyższej woli Najjaśniejszego Imperatora Wszechrosji, najłaskawszym ukazem Jego objawionej, zebrawszy się w Komitet do zaprowadzenia potrzebnych w rządzie wewnętrznym reform przeznaczony i rozpocząwszy pod kierunkiem Jaśnie Wielmożnego radcy tajnego i senatora Imperii Novosilzoff przedwstępną naradę względem przedmiotów roztrząśnieniu naszemu najłaskawiej poruczonych, uznaliśmy najpierwszą potrzebę postanowić dla samych siebie krótkie przepisy, których trzymać się

\footnotetext{
${ }^{4}$ W materiałach Komitetu Cywilnego Reformy brak jest tego listu.
} 
powinni będziemy w odbywaniu prac naszych. Uchwalamy zatem jednomyślnie to, co następuje:

1 .

Gdy skutek rozlicznych praw naszych zawisł od przyzwoitego ich rozkładu pomiędzy członków, a zatem Jaśnie Wielmożny Dyrygujący, rozdzieliwszy za wspólną z nami deliberacją poruczone nam przedmioty na kilka części, wyznaczy dla wyrobienia każdej osobną sekcję z jednego lub więcej członków w miarę potrzeby [złożoną], [s. 10] a Komitet doda im razem pewną liczbę współpracowników z zewnątrz grona swojego. 2.

Prezydencja każdej sekcji zostaje zawsze przy członku Komitetu podług porządku nominacją najwyższą oznaczonego.

3.

Prezydujący każdej sekcji uwiadomić ma niezwłocznie Komitet o organizacji jej wewnętrznej oraz o rozpoczęciu dzieła, w ciągu którego na każdym z posiedzeń naszych winien jest dawać szczegółowe uwiadomienie o dalszych postępach jego.

4.

W wypracowaniu każdego szczegółowego przedmiotu żadna sekcja oddalać się nie może od ogólnych zasad przez Komitet sobie wskazanych.

5 .

Jaśnie Wielmożnego Dyrygującemu zostawia się wolny w każdym czasie przystęp do każdej sekcji, a to dla wglądania, czyli prace posuwają się tak, jak tego najwyższa wola i własny kraju interes wymagają.

6.

Dla stanowienia o projektach przez osobne sekcje przedstawionych, tudzież dla rozwiązywania wątpliwości, które by tę lub ową sekcję w postępie tej pracy zastanawiać mogły, Komitet odbywać będzie dwa na tydzień posiedzenia, to jest w niedzielę i czwartek, [s. 11] zaczynając one o godzinie 11 rannej. W razie nagłej potrzeby doniesionej przez którąkolwiek z sekcji, Jaśnie Wielmożny Dyrygujący mocen jest zwołać nadzwyczajne posiedzenie Komitetu.

7.

Wszelkie materie w Komitecie decydują się prostą większością głosów. Równość zdań Jaśnie Wielmożny Dyrygujący rozstrzyga. Siedmiu członków stanowi komplet.

8.

Członki do składu osobnych sekcji z zewnątrz przybrane znajdować się powinny na posiedzeniu Komitetu, gdy tam projekt ich sekcji do roztrząśnienia przypadnie. Mają wtedy głos doradczy, a opinia większej ich liczby stanowi zawsze jedną kreskę w Komitecie. 9 .

Dla utrzymania protokołu posiedzeń Komitetu oraz wszelkich jego aktów wzywa tenże Komitet Wielmożny Szczurowski protokolistę w Radzie Ministrów Księstwa Warszawskiego.

Jaśnie Wielmożny Prezydujący podaje swoje myśli względem podziału na sekcje ${ }^{6}$, jako to: Prawodawstwa, Administracji Wewnętrznej i Finansów; zważając zaś, że przy-

5 Identyczny tekst „Ordynacji wewnętrznej Komitetu”- BKC, sygn. 5236 IV, s. 25-27.

6 Tekst „Myśli” - zob. podpunkt B). 
jazd Najjaśniejszego Imperatora do Warszawy może prędzej nastąpić, niżeliby sekcje, a następnie Komitet miał dosyć czasu do wygotowania w całości tak obszernego dzieła, sądzi zająć się naprzód wygotowaniem ogólnych projektów w najważniejszych przedmiotach. 1\% Urządzenie [s. 12] administracji krajowej. 2\% Oszczędzenie zbytecznych wydatków. 3\% Poprawienie opłakanego stanu finansów. 4\% Na koniec, że wypadałoby wyrzec o zniesieniu Kodeksu Napoleona bądź w całości, bądź w części. Oświadcza nadto, iż dodałby do tego, a nawet położył na czele wszystkich artykułów ten, który zakończa poruczone Komitetowi przedmioty, gdyby powtórzonymi rozkazami Imperatorskimi nie były już zniesione, i gdyby zabezpieczenie własności nie było pierwszym celem, równie jak pierwszym dobrodziejstwem wszelkiego rodzaju porządku ustanowionego w rządzie.

Czyta potem uwagi swoje Jaśnie Wielmożny Zamoyski, rozbierając polecone przy ukazie Imperatorskim Komitetowi przedmioty, i rzucając myśli względem zasad, podług jakich projekty mogłyby być do przedstawienia monarsze przygotowane ${ }^{7}$.

Wielmożny Szaniawski wystawia w swoim piśmie 1\% rozkład materii na pięć sekcji w stosunku do przedmiotów Komitetowi poleconych. 2\% Ogólne zasady dla każdej sekcji. 3\% Szczególne do każdego punktu objaśnienia. Duchem tego pisma jest, ażeby tak w prawodawstwie, jak [w] administracji stosować się do charakteru i zwyczajów narodowych, a nawet przywrócić dawne nazwiska rzeczy, których pamięć wzbudza na umysłach mieszkańców wiele wrażenia ${ }^{8}$.

Końcem zastanowienia się nad uczynionymi dziś spostrzeżeniami, dla przedsięwzięcia ich decyzji, sesja odłożona na dzień jutrzejszy [...]

8 VII 1814

[s. 13]

Sesja 3

W domu Jaśnie Wielmożnego Ostrowskiego Senatora Wojewody i Prezesa Senatu.

Z udziałem: Nikołaja Nowosilcowa jako prezydujacego, Tomasza Wawrzeckiego, Tomasza Ostrowskiego, Stanistawa Zamoyskiego, Aleksandra Linowskiego, Andrzeja Horodyskiego, Antoniego Bieńkowskiego i Józefa Kalasantego Szaniawskiego, z wezwanych [z] zewnątrz Komitetu Jaśnie Oświecony Książę [Franciszek Ksawery] Lubecki.

Wielmożny Horodyski czyni rozbiór przedmiotów Komitetowi poleconych ${ }^{9}$ i podziela je na trzy sekcje, wyszczególniając, jakie potrzebne będą tym sekcjom materiały $z$ dawniejszych form $i$ organizacji rządowych. $Z$ uczynionego powyżej rozbioru ukazuje dwa główne cele Komitetu. Jeden bliższy i naglejszy: aby niezwłocznie ułożyć i obszerniej wysłowić artykuły najwyższym rozkazem wskazane, przelewając je w formę monarchicznego aktu lub statutu do decyzji $\mathrm{N}^{\mathrm{go}}$ Imperatora za Jego do Warszawy przybyciem, i obejmując w nich te przedmioty, które monarcha uznał za potrzebujące odmiany. Drugi

\footnotetext{
7 Poza treścią protokołu brak wzmianki o istnieniu tego dokumentu.

8 „Uwagi Szaniawskiego względem podziału prac Komitetu na sekcje” nie zostały złożone do akt. BKC, sygn. $5236 \mathrm{IV}$, s. 5.

9 Dokument pt. „Uwagi Horodyskiego względem podziału przedmiotów Komitetowi poleconych na sekcje" nie został złożony do akt Komitetu. BKC, sygn. 5236 IV, s. 5.
} 
dalszy cel. Po odebraniu rzeczonego aktu rozwinąć zawarte w nim zasady i wygotować obszerniejsze urządzenia. Mówiąc o przejściu z kodeksu [s. 14] Napoleona do nowej sądownictwa epoki, wnosi, czyliby dla uniknienia zamieszania nie wypadałoby chwycić się sposobu użytego w Danii, przez ustanowienia sądów pojednawczych, które by w przeciągu tych lat, jakby się formowała nowa biega [sic!] prawa, ukończyły wszystkie sprawy i naród z nich oczyszczony przeprowadziły do nowego porządku rzeczy.

Myśl ta znalazła zgodne za sobą zdanie członków Komitetu z przydaną uwagą przez Jaśnie Wielmożnego Prezesa Senatu, iż gdy sądy pojednawcze z natury instytucji swojej nie mogą ostatecznie kończyć spraw, tam gdzie by strony przestać na ich wyroku zgodnie nie chciały, wypadałoby zaprowadzić sądy na kształt dawnych kompromisarskich, które by ostatecznie w sprawach między stronami wyrokowały. Wielmożny Horodyski znajdował załatwienie tej uwagi w przyjęciu sposobu użytego w Danii sądów pojednawczych, gdzie był sąd drugi stanowczy ostatecznie w tych sprawach, które przez sądy pojednawcze zagodzonymi być nie mogły.

Po roztrząśnieniu uwag względem podziału pracy na sekcje uchwalono ich cztery.

Pierwszą Sekcję Administracyjną do artykułów $1^{\circ}$ i $5^{\circ}$ zawartych w nocie do ukazu imperatorskiego przyłączonej, której cała osnowa wciągniona jest do protokołu pierwszego posiedzenia. [s. 15] Tę pierwszą sekcję składają: Jaśnie Wielmożni Zamoyski, Linowski i Horodyski.

Drugą Sekcję Sądową i Miast do artykułów 20 i $4^{\circ}$ Grabowski, Bieńkowski, Szaniawski.

Trzecią Sekcję Skarbową do artykułów $3^{\circ}$ i $6^{\circ}$ Matuszewicz, Minister Skarbu, i Horodyski.

Czwartą Sekcję Edukacyjną i Duchowieństwa do artykułów $7^{\circ}$ i $8^{\circ}$ Zamojski, Ks. Koźmian, Szaniawski.

Wszystkie zaś sekcje pamiętać mają o artykule 9., który mówi o zabezpieczeniu świętego prawa własności ${ }^{10}$.

Pomienione sekcje pracować będą naprzód nad ułożeniem zasad względem przedmiotów między nie podzielonych i przyniosą do decyzji Komitetu swoje projekty, po której przelane być mają w jeden projekt podług formy dekretu monarchicznego dla przedstawienia Najjaśniejszemu Imperatorowi za jego do Warszawy przybyciem.

Każda sekcja upatrzy sobie potrzebnych współpracowników [z] zewnątrz swego grona i poda ich do oznaczenia Komitetowi na przyszłym jego posiedzeniu przypadającym dnia 10. bieżącego miesiąca.

10 VII 1814

\section{Sesja 4}

W domu Jaśnie Wielmożnego Ostrowskiego Prezesa Senatu.

Z udziałem: Nikołaja Nowosilcowa jako prezydujacego, Tomasza Wawrzeckiego, Tomasza Ostrowskiego, Stanistawa Zamoyskiego, Aleksandra Linowskiego, Andrzeja Horodyskiego, Antoniego Bieńkowskiego i Józefa Kalasantego Szaniawskiego.

10 Identyczny tekst zredagowany jako uchwała Komitetu znajduje się w „Papierach Komitetu Reformy co do Ogólności” - BKC, sygn. 5236 IV, s. 29. 
Na przełożenia ${ }^{11}$ sekcji oznaczone są dla wspólnej w nich pracy następujące osoby

1\% Do Sekcji Administracyjnej

Koźmian Referendarz Rady Stanu

Stanisław Nowakowski

Godlewski - posłowie na Sejmie

Tokarski - Sekretarz G[enera]lny Głównej Izby Obrachunkowej

$2 \%$ do Sekcji Ustaw[odaw]czej i Miast

Ks. opat Bohusz

Woźnicki Prokurator Sądu Kasacyjnego

Borakowski

Skarżyński - sędziowie apelacyjni

Kozłowski Mecenas

Bandtkie Notariusz Publiczny

3\% Do Sekcji Skarbowej zostawiono Jaśnie Wielmożnemu Dyrygującemu Novosilzoff wezwać upatrzone osoby.

4\% Do Sekcji Edukacyjnej i Duchowieństwa

Ks. Woronicz Radca Stanu

Ks. Prażmowski ${ }^{12}$.

[s. 17] Wezwane będą pomienione osoby przez prezydującego względem każdej sekcji. $[\ldots]$

„Myśli prezydującego Nowosilzoff względem podziatu prac Komitetu na sekcje”.

Or. Biblioteka Książąt Czartoryskich, rkps, sygn. 5236 IV, Papiery Komitetu Reformy co do ogólności, administracji wewnętrznej, prawodawstwa i sądowości, materii skarbowej, duchowieństwa i edukacji i korespondencji z Komitetem Wojskowym.

Pres. na sesji Komitetu d. 7 lipca 1814.

[Myśli prezydującego Novosilzoff względem podziału prac Komitetu na sekcje ${ }^{13}$ ] [s. 17] Le Comité, constitué par Sa Majesté l'Empereur, et chargé de Lui présenter lors de Son passage par Varsovie, des projets de réforme dans plusieurs branches d'administration publique, dont il Lui a plu d'indiquer les objets désirant que chacun de ses membres prépare pour la première séance, un avis par écrit, sur le mode, la division et la distribution du travail dont le Comité est chargé, sur les principes qui doivent servir de base à la reforme de chaque objet en particulier et sur d'autres sujets y relatifs; je prends

\footnotetext{
11 Przełożenia - przedłożenia.

12 Identyczny tekst zredagowany jako uchwała Komitetu znajduje się w „Papierach Komitetu Reformy co do Ogólności” - BKC, sygn. 5236 IV, s. 33.

13 Tytuł przepisany na podstawie Wykazu pism Komitetu. Sam tekst nie został zaopatrzony ani w tytuł, ani $\mathrm{w}$ datę.
} 
la liberté de soumettre au Comité sur plusieurs de ces points, quelques idées générales, qui ont pour objet d'accorder nos sentiments sur les choses les plus essentielles à décider, avant de mettre la main à l'œuvre et sur la manière d'y procéder.

Qu'il me soit permis de commencer d'abord par arrêter l'attention du Comité sur une observation très judicieuse qu'un de nos membres a faite dans la dernière séance et qui est celle, que le premier pas à faire, devrait être celui de déterminer quels sont les objets contenus dans la Note de réforme [s. 18] approuvée par Sa Majesté l'Empereur, qui par leur nature et leur importance, présentent aussi bien la nécessité que la possibilité d'être définitivement réglés par Sa Majesté lors de Son passage par Varsovie et quels sont les autres qui doivent être destinés à recevoir simplement de Sa Volonté Suprême l'impulsion nécessaire pour être mis dans la voie qui leur est propre.

Cette distinction est d'autant plus nécessaire que l'arrivée très prochaine de $\mathrm{Sa}$ Majesté l'Empereur nous laisse très peu de temps à notre disposition et qu'il ne faudrait pas moins que la réunion de tous moyens et de tous nos efforts pour parvenir à préparer quelque chose qui pût être, comme je l'ai dit plus haut, réglé définitivement.

Les réformes qui doivent avoir la préférence sur les autres, sont sans contredit, celles qui sont calculées à porter le remède le plus prompt aux maux les plus grands.

En partant de ce principe et en examinant attentivement la note des objets de réforme qui nous est communiquée, je suppose qu'il est difficile de ne pas tomber d'accord [s. 19] que ce qui presse le plus, c'est de porter remède $1^{\circ}$ à l'organisation vicieuse des Départements tant sous le rapport de l'administration intérieure que sous celui des finances. $2^{\circ}$ Aux dépenses énormes que compte en général l'administration (: ce qui rentre quoique indirectement dans le $1^{\text {er }}$ objet :). $3^{\circ}$ à l'état déplorable de la partie des finances en général autant sous le rapport de la comptabilité qui est si vicieuse qu'on peut dire qu'elle est presque nulle, que sous celui de la pénurie, qui est si grande qu'elle suffit à peine aux dépenses les plus pressantes. $4^{\circ}$ Enfin, il convient à droit aussi de faire entrer dans cette catégorie l'abolition du Code Napoléon soit en entier soit en partie.

Je n'aurais point hésité d'ajouter à cela et de mettre à la tête de tous ces articles celui qui termine la note, si par des ordres réitérés de Sa Majesté l'Empereur, les réquisitions n'étaient point déjà abolies et si la garantie des propriétés ne fut le premier but, aussi bien que le premier bienfait de toute espèce d'ordre établi dans un gouvernement.

[s. 20] En supposant que le Comité convienne avec moi que les objets que je viens de citer, sont les plus importants et qu'ils exigent qu'on s'en occupe exclusivement et le plus tôt possible; je trouve un vrai plaisir à l'informer, que pour ce qui concerne les premier et second objets, on y travaille déjà depuis quelque temps et que bientôt je serai à même de porter à la discussion du Comité un plan qui embrassera ces deux objets dans toute leur étendue. Quant aux défauts de la comptabilité et aux moyens d'y remédier, je m'en suis aussi occupé et j'aurai également l'honneur de présenter incessamment au Comité sur cet objet, un travail qui contiendra l'exposé de tous les vices du système qu'on suit à présent et de tous les motifs qui réclament un changement. Il sera en outre accompagné des modèles, des nouveaux livres et bordereaux que je me propose de substituer à ceux qui ont existé jusqu'à présent et qui sont la source principale de toutes les confusions qui règnent dans cette partie. Le Comité n'ignore point qu'on ne pourrait introduire [s. 21] le nouveau système en entier et particulièrement substituer d'autres livres qu'avec le commencement de l'année financière - sans quoi l'on risquerait d'embrouiller les comptes 
de manière à n'en plus sortir. Néanmoins, il serait toujours extrêmement utile de fixer le système dès à présent et de préparer tout ce qui est nécessaire pour cette époque.

Je n'entreprendrai point de décider sur l'abolition subite du Code civil, soit en entier, soit en partie. Ce sujet n'a point été assez débattu pour que la lumière qui doit rejaillir de la discussion soit assez grande pour nous éclairer sur tous les inconvénients qui peuvent en résulter ; ainsi que sur tous les moyens qu'on peut avoir à sa disposition pour les écarter. Au surplus, j'abandonne ce sujet avec toute la confiance possible à des hommes plus habiles que moi et qui connaissent mieux les rapports particuliers à ce pays-ci sur cette nature d'affaire. Mais il est certain qu'il n'y aurait rien de plus désirable que les lois du pays vinssent remplacer le plus tôt possible les [s. 22] lois étrangères.

Le Comité ne pouvant s'occuper in plenum de chaque objet qui sera présenté, sans risquer de mettre beaucoup de retard dans ses travaux, qu'il est essentiel d'accélérer, qu'il me soit permis de Lui proposer de se diviser en trois sections, dont l'une s'occuperait de la législation, la seconde de l'administration intérieure et la troisième des finances. Les papiers relatifs à chacune de ces branches d'administration, seraient renvoyés dans leurs sections respectives et après avoir été examinés et discutés, il en serait fait en rapport in plenum.

Novosilzoff

lû au Comité de reforme le 7 Juillet 1814.

[Myśli prezydującego Novosilzoff względem podziału prac Komitetu na sekcje] - ttumaczenie

[s. 17] Komitet, utworzony przez Jego Wysokość Cesarza, któremu powierzone zostało zadanie przedstawienia Jego Wysokości w czasie Jego wizyty $w$ Warszawie projektów reform w kilku dziedzinach administracji publicznej, i któremu zechciat wskazać tematy, mając życzenie, aby każdy z jego członków przygotował na pierwsze posiedzenie pisemna opinię w sprawie sposobu prowadzenia, podziału i rozłożenia prac, za które Komitet jest odpowiedzialny, w sprawie zasad, które w szczególności powinny stanowić podstawę reformy poszczególnych przedmiotów, oraz $w$ sprawie tematów z tym powiązanych; pozwalam sobie poddać Komitetowi kilka ogólnych pomysłów dotyczacych kilku z tych punktów, których celem jest uzgodnienie naszych poglądów co do najistotniejszych kwestii, w sprawie których maja zostać podjęte decyzje, zanim zabierzemy się do dzieła, oraz co do sposobu procedowania.

Niech wolno mi będzie w pierwszej kolejności zwrócić uwage Komitetu na bardzo celna uwage wyrażona przez jednego z naszych członków na ostatnim posiedzeniu, a mianowicie, że pierwszym krokiem, jaki należy podjać, jest określenie przedmiotów zawartych w Nocie [w sprawie] Reformy [s. 18], zatwierdzonej przez Jego Wysokość Cesarza, które ze względu na ich charakter $i$ znaczenie zarówno wymagaja, jak $i$ daja możliwość ostatecznego ich uregulowania przez Jego Wysokość Cesarza w czasie jego wizyty $w$ Warszawie, i określenia innych, które powinny zwyczajnie otrzymać Jego Najwyższa Wola niezbędny bodziec, by zostały popchnięte na właściwa im drogę.

To rozróżnienie jest tym bardziej konieczne, że mające nastapić $w$ bliskim czasie przybycie Jego Wysokości Cesarza pozostawia nam bardzo mało czasu do dyspozycji $i$ wymaga co najmniej zebrania wszystkich środków i skoncentrowania naszych wysit- 
ków, aby przygotować coś, co, jak już wcześniej powiedziatem, mogłoby zostać ostatecznie uregulowane.

Reformy, które musza mieć pierwszeństwo przed innymi, to bez watpienia reformy, które nastawione sq na to, by zapewnić jak najszybciej lek na największe bolaczki.

Wychodzac od tej zasady i uważnie analizując przekazana nam notę dotyczaca przedmiotów reformy, przypuszczam, że trudno chyba nie zgodzić się z tym, [s. 19] że najbardziej naglace jest zaradzenie $1^{\circ}$ złej organizacji departamentów, zarówno $w$ zakresie administracji wewnętrznej, jak i finansów. $2^{\circ}$ ogromnym wydatkom, kładzionym ogólnie na administracje (co wchodzi, choć pośrednio, do pierwszego przedmiotu), $3^{\circ}$ żałosnemu stanowi części finansów ogólnie, zarówno pod względem rachunkowości, która jest w tak opłakanym stanie, że można powiedzieć, iż prawie nieistniejąca, jak i pod względem niedoborów w skarbcu, które sa tak wielkie, że ledwie wystarcza na pokrycie najbardziej naglacych wydatków, $4^{\circ}$ wreszcie, stuszne jest również włączenie do tej kategorii zniesienia Kodeksu Napoleona w catości lub w części.

Nie zawahatbym się dodać do tego i postawić na czele wszystkich tych artykutów tego, który kończy notę, gdyby na mocy powtarzajacych się rozkazów Jego Wysokości Cesarza rekwizycje nie zostaty juz zniesione i gdyby zagwarantowanie [ochrony] wlasności nie było pierwszym celem, jak również pierwszym dobrodziejstwem wszelkiego rodzaju porzadku ustanowionego $w$ rzadzeniu.

[s. 20] Zakładając, że Komitet zgodzi się ze mna, że przedmioty, które wymienitem sq najważniejsze $i$ że wymagaja zajęcia się nimi wyłacznie $i$ w jak najszybszym czasie, z prawdziwa przyjemnościa informuję, że jeśli chodzi o pierwszy i drugi przedmiot, pracujemy nad nim już od pewnego czasu i wkrótce będę mógt poddać pod dyskusję Komitetu plan, który obejmie te dwa przedmioty w catym ich zakresie. Co się tyczy niedostatków systemu rachunkowości i środków zaradczych, również się nimi zajątem $i$ będę miat zaszczyt przedstawić wkrótce Komitetowi prace dotyczaca tego przedmiotu, która zawierać będzie przedstawienie wszystkich wad obecnie stosowanego systemu oraz powodów, dla których konieczne jest przeprowadzenie zmian. Towarzyszyć jej będa również wzory, nowe księgi i formularze, którymi proponuję zastapić te, które istniaty do tej pory i które sa głównym źródtem catego zamieszania, jakie panuje w tej dziedzinie. Komitet jest świadomy, że możliwe będzie wprowadzenie [s. 21] nowego systemu w całości, a w szczególności nowych ksiag dopiero z początkiem [nowego] roku budżetowego - $w$ przeciwnym bowiem razie istniałoby ryzyko zagmatwania rozliczeń $w$ sposób nie dajacy się opanować. Niemniej jednak byłoby niezwykle przydatne ustalenie systemu już obecnie i przygotowanie wszystkiego, co jest konieczne na przyszłość.

Nie podejme sie zdecydowania o nagtym zniesieniu Kodeksu cywilnego czy to w catości, czy w częśsi. Temat ten nie byt wystarczajaco przedyskutowany, aby wyjaśnienia wynikajace z dyskusji byty dość wyraźne, aby rzucić światto na wszystkie niedogodności, które moga z tego wyniknać; a także na wszystkie środki, które powinny być zapewnione, aby ich uniknać. Ponadto pozostawiam ten temat z catym możliwym zaufaniem mężom, którzy sq bardziej zręczni ${ }^{14}$ ode mnie i posiadaja lepsza znajomość szczególnych stosunków panujacych $w$ tym kraju $w$ tej dziedzinie. Jednak jest pewne, że nie bytoby nic

\footnotetext{
14 Wykwalifikowani.
} 
bardziej pożądanego od jak najszybszego zastapienia prawem krajowym [s. 22] praw zagranicznych.

Ponieważ Komitet nie może zajmować się na posiedzeniu plenarnym każdym z prezentowanych przedmiotów, nie ryzykując przy tym dużego opóźnienia prac, które koniecznie należy przyspieszyć, niech mi wolno będzie zaproponować podzielenie go na trzy sekcje, z których jedna zajmie się prawodawstwem, druga administracja wewnętrzna, a trzecia finansami. Dokumenty dotyczace poszczególnych działów administracji zostana przestane do odpowiednich sekcji, a po ich przeanalizowaniu i omówieniu raport przedstawiony zostanie na posiedzeniu plenarnym.

Odczytano na posiedzeniu Komitetu Reformy w dniu 7 lipca 1814 r.

Novosilzoff

\section{3}

Fragmenty protokolu posiedzeń Komitetu Cywilnego Reformy z sesji 4 i 5 obrad toczacych się 10 i 14 lipca obejmujące wstępna dyskusję nad planem reformy kodyfikacyjnej Komitetu Cywilnego. Or. Biblioteka Książąt Czartoryskich, rkps, sygn. 5233 IV, Protokół posiedzeń Komitetu Reformy od jego rozpoczęcia się dnia 4 lipca 1814.

10 VII 1814

Sesja 4

W domu Jaśnie Wielmożnego Ostrowskiego Prezesa Senatu.

Z udziałem: Nikołaja Nowosilcowa jako prezydującego, Tomasza Wawrzeckiego, Tomasza Ostrowskiego, Stanisława Zamoyskiego, Aleksandra Linowskiego, Andrzeja Horodyskiego, Antoniego Bieńkowskiego i Józefa Kalasantego Szaniawskiego.

[s. 17] [...] Wielmożny Bieńkowski czyta swoje uwagi nad artykułem 2 przedmiotów wskazanych Komitetowi, a poruczonym Sekcji Sądowej czyli Ustaw[odaw]czej ${ }^{15}$, dzieląc ten artykuł na dwie części: pierwsza zawiera, że kodeks Napoleona cywilny i procedury sądowej powinien być uchylony, jak tylko będzie można; a na to miejsce zdałoby się wprowadzić prawa polskie i Statut litewski, jako też formy sądowe używane przed zaprowadzeniem procedury francuskiej, i że Komitet roztrząśnie, czyli te kodeksy mają być zniesione całkowicie lub w części. Druga część niniejszego artykułu wyraża, iż Komitet poda także plan do ustanowienia osobnej komisji, która by się zajęła układaniem nowego kodeksu cywilnego, kryminalnego i procedury, niemniej ostateczną organizacją porządku sądowego. Obok takiego przepisu zwraca Wielmożny Bieńkowski uwagę na ostatnie wyrazy najwyższego rozkazu, iż wolą jest Jego Imperatorskiej Mości,

15 W „Wykazie pism wystawionych w Komitecie Cywilnym reformy podzielonych na materię: Co do prawodawstwa i sądowości” umieszczona została adnotacja, iż „Uwagi J[aśnie] W[ielmożnego] Bieńkowskiego względem Kodeksu Cywilnego i procedury” zostały „,odesłane do Sekcji Sądowej i niezwrócone, lecz poniżej znajdują się też same powtórzone pod dniem 16 października” - BKC, sygn. 5236 IV, s. 199. 
ażeby w ogólności wszystkie odmiany w teraźniejszym systemacie rządowym Księstwa działy się z najmniejszą jak tylko można nagłością, dla uniknienia szkodliwych skutków, jakie pociąga za sobą wszelkie gwałtowne wstrząśnienie. To ostatnie prawidło, nauką doświadczenia po wszystkich krajach wsparte, mając na szczególnym względzie, rozbiera porządkiem wszystkie tytuły kodeksu cywilnego i okazuje, które przepisy jako nieszkodliwe wypada utrzymać aż do terminu, jaki się naznaczy do wprowadzenia ułożyć się mającej innej księgi prawa; a które jako niedogodne, przeciwne opinii publicznej i uciążliwe wypada i można zaraz bez zamieszania uchylić, a inne zgodniejsze z życzeniem i interesem mieszkańców zaprowadzić. [s. 18] Do liczby ostatnich uchyleniu niezwłocznie podpaść mających łączy cofnienie wyjednanych ubocznie lub nielegalnie wypadłych dekretów królewskich, a mianowicie dekretu 10 października 1809 prawem przechodnim nazwanego, tudzież reskryptów ministerialnych naruszających niepodległość sądownictwa i podających w moc ministra całą wyroków sądowych egzekucję. Co się tyczy kodeksu procedury, zostawiając ją także do pewnego terminu wprowadzenia innej, sądzi, iż samą egzekucję w tym Kodeksie jako uciążliwą wypada zaraz odmienić, przepisując stosowniejszą do natury majątków.

Komitet roztrząśnienie tych wniosków i układ projektu odsyła do Sekcji Ustaw[odaw]czej.

Jaśnie Wielmożny Prezydujący podaje rozwadze Komitetu, czyli nie wypadnie potrzeba przedłużeniu juristitium, aby w takim przypadku mógł być wcześnie przygotowany projekt do przedstawienia Najjaśniejszemu Imperatorowi.

Polecono Sekcji Ustaw[odaw]czej zastanowić się nad tym ważnym przedmiotem i podać Komitetowi swoje uwagi. [...]

14 VII 1814

Sesja 5

W domu Jaśnie Wielmożnego Ostrowskiego Prezesa Senatu.

Z udziałem: Nikotaja Nowosilcowa jako prezydujacego, Tomasza Wawrzeckiego, Tomasza Ostrowskiego, Stanistawa Zamoyskiego, Tadeusza Matuszewica, Aleksandra Linowskiego, ks. Józefa Koźmiana, Antoniego Bieńkowskiego i Józefa Kalasantego Szaniawskiego.

[s. 19] Sekcja Edukacyjna i Duchowieństwa uwiadamia, że już zasady w przedmiotach sobie poruczonych ugodziła, idzie tylko o ułożenie ich w formie projektu, po czym będzie mogła przynieść swoją pracę do decyzji Komitetu.

Roztrząsano w ogólności, jaką zasadę położyć teraz wypadnie względem prawa cywilnego i procedury objętych artykułem 2 najwyższego rozkazu danego Komitetowi.

$Z$ jednej strony miano na względzie, aby w przyszłości z dotychczasowych praw do innych przepisać się mających, nie sprawić przez nagłość gwałtownego wstrząśnienia i zamieszania, z drugiej, aby można jak najprędzej pozbyć się praw i form obcych, a mianowicie tego, co w nich jest niestosownie uciążliwym dla kraju.

Uważano, iż obu tym względom mogłaby dogodzić następująca zasada, to jest że Kodeks Napoleona cywilny i procedury zostaje niniejszym aktem uchylony, obowiązywać tylko będzie do pewnego terminu, jaki się oznaczy, niżeli nowa księga prawa 
ułożoną i do wykonania wprowadzoną zostanie, inaczej jednak trwać nie ma i do tego czasu, jak z wyłączeniami, które się zaraz oznaczą i innymi przepisami niezwłocznie zastąpione zostaną. Takowe uchylenie zaraz kodeksu nie będzie przeszkadzać, aby komisja mająca być ustanowioną do ułożenia nowej księgi prawa nie mogła z niego wyjąć i do tej ostatniej przenieść, co znajdzie stosownym i dobrym dla kraju.

Zastanawiano się w szczególności nad dotychczasowym [s. 20] przepisem, który sprawy w przedmiotach spornych między rządem a prywatnymi oddaje pod sądzenie radom prefekturalnym, uznając, że takowy sąd, będąc niejako i sędzią, i stroną, nie zabezpiecza należycie własności prywatnej, polecono Sekcji Ustaw[odaw]czej, czyli Sądowej, aby w układzie swego projektu pomienione sprawy przywiązała do sądów zwyczajnych. [...]

\section{Bibliografia}

\section{Źródła rękopiśmienne}

Biblioteka Książąt Czartoryskich, sygn. 5233 IV, 5236 IV, 5239 IV, 5242 V, 5259 IV i 5262 IV. Biblioteka Naukowa PAN i PAU w Krakowie, sygn. 152, cz. 1.

Biblioteka im. Zielińskich Towarzystwa Naukowego Płockiego, sygn. 502.

Gosudarstvennyj Archiv Rossijskoj Federacji w Moskwie, Fond 1165, opis 3, dieło 14.

\section{Źródła wydane}

Dziennik ks. Adama Jerzego Czartoryskiego 1813-1817, oprac. M. Karpińska, Warszawa 2016.

Dziennik Praw [Księstwa Warszawskiego], t. I.

Dziennik Praw [Księstwa Warszawskiego], t. II.

Herburt J., Statuta y przywileje koronne z łacińskiego języka na polskie przełożone, nowym porządkiem zebrane, Kraków 1570.

Kodeks Stanisława Augusta. Zbiór dokumentów, wyd. S. Borowski, Warszawa 1938.

Kołłątaj H., Uwagi nad teraźnieyszym położeniem tej części ziemi polskiej, którą od pokoiu tylżyckiego zaczęto zwać Xięstwem Warszawskim, Lipsk 1808.

Koźmian K., Pamiętniki, t. II, Warszawa 1972.

Ostrowski A., Żywot Tomasza Ostrowskiego, ministra Rzeczypospolitej później prezesa Senatu Księstwa Warszawskiego i Królestwa Polskiego oraz rys wypadków krajowych od 1763 r. do 1817 r. przez autora pomystów o potrzebie reformy krajowej, t. 2, Paryż 1840.

Trembicki [Trębicki] A., Prawo polityczne i cywilne Korony Polskiej i Wielkiego Księstwa Litewskiego, to jest: Nowy zbiór praw Obojga Narodów od roku 1347 aż do teraźniejszych czasów, t. 1-2, Warszawa 1789-1791.

Węgrzecki S., Przestrogi do utworzenia Królestwa Polskiego [w:] Wybór tekstów źródtowych z Historii Polski w latach 1795-1864, red. S. Kieniewicz, T. Mencel, W. Rostocki, Warszawa 1956. 


\section{Opracowania}

Askenazy S., Zagrożenie Kodeksu Napoleona przy utworzeniu Królestwa Polskiego [w:] idem, Szkice i portrety, Warszawa 1937.

Askenazy S., Założenie Królestwa Polskiego w 1815 r. [w:] idem, Szkice i portrety, Warszawa 1937.

Bardach J., Recepcja w historii państwa i prawa [w:] idem, Themis a Clio, czyli prawo a historia, Warszawa 2001.

Bojasiński J., Rządy tymczasowe w Królestwie Polskiem: maj-grudzień 1815, Warszawa 1902.

Gałędek M., Koncepcje i projekty nowego ustroju administracji dla przyszłego Królestwa Polskiego. Studium z dziejów myśli administracyjnej, Sopot 2017.

Gałędek M., The Problem of Non-Adaptability National Legal Heritage. Discussion on the Reform of Civil Law in Poland in the Course of Work of Reform Committee in 1814, „Romanian Journal of Comparative Law" 2017, t. 8, z. 1.

Gałędek M., Wpływ wojen napoleońskich na wzrost antagonizmu do biurokracji w polskiej myśli administracyjnej, „Studia z Dziejów Państwa i Prawa Polskiego” 2019, t. 22 [w druku].

Gałędek M., Zagadka projektu Platera. Próba rekonstrukcji pierwszej fazy prac nad Ustawa konstytucyjna z 1815 r. [w:] Księga Jubileuszowa z okazji siedemdziesięciolecia urodzin oraz czterdziestopięciolecia pracy naukowej Pana Profesora Andrzeja Szmyta, red. P. Uziębło i in., Gdańsk [w druku].

Gałędek M., Klimaszewska A., A Controversial Transplant? The Debate on the Adaptation of the Napoleonic Code on Polish Territory in the Early Nineteenth Century, „Journal of Civil Law Studies" 2018, t. 11, z. 2.

Gałędek M., Klimaszewska A., Stosunek polskich elit do prawa francuskiego po upadku Napoleona, „Studia z Dziejów Państwa i Prawa Polskiego” 2018, t. 21.

Grodziski S., Studia galicyjskie: rozprawy i przyczynki do historii ustroju Galicji, Kraków 2007.

Grynwaser H., Kodeks Napoleona w Polsce [w:] idem, Pisma, t. 1, Wrocław 1951.

Handelsman M., Rozwój narodowości nowoczesnej, tłum. J. Sękowski, Warszawa 1973.

Kallas M., Konstytucja Księstwa Warszawskiego - jej powstanie, systematyka i główne instytucje w zwiąku z normami szczegółowymi i praktyka, Torun 1970.

Katalog rękopisów Biblioteki Książą Czartoryskich w Krakowie. Sygnatury 5214-5319, oprac. J. Pezda, Kraków 2001.

Kraushar A., W setna rocznicę Kodeksu Napoleona, „Gazeta Sądowa Warszawska” 1908, nr 22, $\mathrm{z}$ dnia $28 \mathrm{~V}$.

Leśnodorski B., Liberałowie, „technokraci” i republikanie [w:] idem, Historia i wspótczesność, Warszawa 1967.

Litauer J.J., Przeciwnicy Kodeksu, „Gazeta Sądowa Warszawska” 1908, nr 22, z dnia 28 V.

Mencel T., Feliks Lubieński: minister sprawiedliwości Księstwa Warszawskiego (1758-1848), Warszawa 1953.

Mencel T., L'Introduction du Code Napoléon dans le Duché du Varsovie (1808), CPH, 1949, t. 1, z. 2.

Mycielski M., „Miasto ma mieszkańców, wieś obywateli”. Kajetana Koźmiana koncepcje wspólnoty politycznej (do 1830 roku), Wrocław 2004.

Pomianowski P., Postulat narodowego charakteru prawa w pracach kodyfikacyjnych doby Królestwa Kongresowego, CPH, 2019, t. 71, z. 1.

Pomianowski P., Rozwód w XIX wieku na centralnych ziemiach polskich. Praktyka stosowania Kodeksu Napoleona w latach 1808-1852, Warszawa 2018.

Pomianowski P., Z problematyki rozwodów w Księstwie Warszawskim, CPH, 2013, t. 65, z. 2. 
Przygodzki J., Komitet Organizacyjny Cywilny i jego prace nad reorganizacja administracji na terenach Księstwa Warszawskiego „Acta Universitatis Vratislaviensis” 1999, nr 2144, prawo CCLXIV.

Przygodzki J., Rada Najwyższa Tymczasowa Księstwa Warszawskiego 1813-1815. Organizacja i działalność, Wrocław 2002.

Radwański Z., Wąsicki J., Wprowadzenie pruskiego prawa krajowego na ziemiach polskich, CPH, 1954, t. 6, z. 1.

Sobociński W., Historia ustroju i prawa Księstwa Warszawskiego, Warszawa 1964.

Sobociński W., Jan Wincenty Bandtkie obrońca Kodeksu Napoleona (Przyczynki biograficzno-naukowe i memoriat z 1815 r.), ,Rocznik Lubelski” 1960, nr 3.

Sobociński W., Rozwój ustawodawstwa cywilnego w Królestwie Polskim i w Rosji do rosyjskiej reformy sądowej (Zarys historyczno-porównawczy), „Annales Universitatis Mariae Curie-Skłodowska" 1965, sectio G: Ius, vol. 12.

Sójka-Zielińska K., Kodeks Napoleona. Historia i wspótczesność, Warszawa 2008.

Witkowski W., Uwagi o urzędzie ministra sprawiedliwości w Królestwie Polskim (1815-1867), „Acta Universitatis Wratislaviensis” 2010, nr 3270, prawo CCCXI.

Zarychta M., Propozycje ustrojowe Adama Jerzego Czartoryskiego i jego otoczenia (1813-1815), „Przegląd Historyczny” 2006, t. 97, z. 4.

Zawadzki W.A., Recenzja Dziennika ks. Adama Jerzego Czartoryskiego 1813-1817, „Kwartalnik Historyczny" 2018, nr 1. 